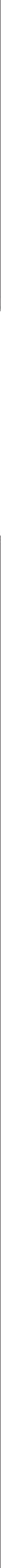





\section{The Enigmatic Puppets of Important Czech Marionettists, the Flachs}

The Flachs family belongs among the distinctive marionettists of the nineteenth century. ${ }^{1}$ The dynasty most probably originated in South Bohemia. However, the largest body of evidence of their activities comes from Moravia in a later period, at a time when they operated together with the family troupes of Pfleger, Šimek, Kučera, Nový, Fink, Janeček, Kopecký, Vala, Hergot, Antonín Scheich, Josef Ruml, Josef Pecha and others.

The inventories of the Flachs family contains marionettes of an original kind that is distinctive from the pieces of other marionettist families, as well as from those produced by known woodcarving workshops. Moravian marionettists generally used marionettes made by established carvers, some of them local - such as František Šiška, Josef Staněk, Bohumil Tichý, Jaroslav Vaněk or Stanislav Nový. However, the origin of the Flachs' puppets is mysterious; whether they made them themselves, as is often claimed, has not been fully proven. This essay analyses the traditional puppets of the Flachs - marionettes, glove puppets and rod puppets controlled from below (known as mikrlata) - that were allegedly made by the members of the family, and examines their visual appearances, their artistic merit, their indications of professionalism, their technologies and carving styles, and the inventiveness of their creator. My study is based on the objects deposited in the collections of the Moravian Museum (Moravské zemské muzeum, MZM) in Brno as well as in other Czech collections.

Czech puppet (or marionette) theatre forms an integral part of the history of Czech theatre in the eighteenth and nineteenth centuries. The productions of travelling

1 The publication was made with the financial support of the Czech Ministry of Culture as part of the institutional finances of the long-term conceptual development of the research organisation Moravské zemské muzeum (DKRVO, MK000094862). 
marionettists, known as folk puppeteers, represent and, in a way, substitute for the unique phenomenon of the comedians' type of theatre that had existed and been active in many European theatre cultures. In the Czech milieu, favourable conditions for such activities of secular professional theatre performed in the vernacular came only in the late eighteenth century, with the reforms initiated under Joseph II, with the abolishment of serfdom of 1781, as well as with the gradual economical and political emancipation of Czech society. The earliest productions of strolling puppeteers became the very first points of contact for the general populace with a theatre culture. During the national revival of the nineteenth century, marionette theatre crystallised into a unique theatrical form that fulfilled an undoubtedly influential role of forming a national theatre culture, namely one that pertained in both towns and in the country. A long-lasting period of formation eventually resulted in an enclosed, relatively stable and highly stylised theatre type. Despite its continuing intensive activities, at the turn of the twentieth century it started to be perceived as out-dated and stagnant. Detrimental to it were also the new social and economic conditions and the rising competition of amateur theatre. In the 1950s, travelling marionette theatre came to an end as a phenomenon through legislative action at which time it was no longer officially recognised as a business trade. It can be taken for granted that had it not been for the forceful termination of travelling or traditional marionette theatre, it would have survived in some dignified form to the present day. Examples of countries in which traditional puppetry has kept its place side by side with new trends can be called to witness - such as Bruno Leone and the Istituto delle Guarattelle in Italy; Professor Clive Chandler and Punch and Judy in the UK; or the late Anton Anderle, Ivan Gontko and Juraj Hamar in Slovakia. The hypothetical path towards the theatre form's development into an 'art' should not also be ruled out; there had been such indications in the activities and productions of several marionettists, such as Jan Nepomuk Laštovka (1824-1877), Vilém Maizner (1846-1906) and his children, Antonín Kaiser (ca.1848-1906), Karel Novák (1850-1933) or Antonín Kopecký (1892-1953). In the Czech context, however, due to the forceful, deformed denigration of all aspects of marionette theatre (including the positives) and its degradation into a primitive and simple-minded phenomenon, such continuity was rendered impossible.

Marionette theatre as a performing art is indelibly linked with professional folk trades and crafts, such as woodcarving, colouring and costuming the puppets - or the making of stage decorations; in a Czech context, it created an exceptionally strong and firm tradition of puppet theatre that has manifested itself incessantly in two mutually influencing and permeating lines: folk theatre (amateur puppetry in all its forms) and professional theatre (statutory theatre, independent companies and solo performers). This tradition is permanently modified with experiments, original creative efforts and trends. Certain specific features of puppet theatre define its absolute theatricality: its almost exemplary illusiveness, its reliance on metaphor, stylisation and its unreal nature, 


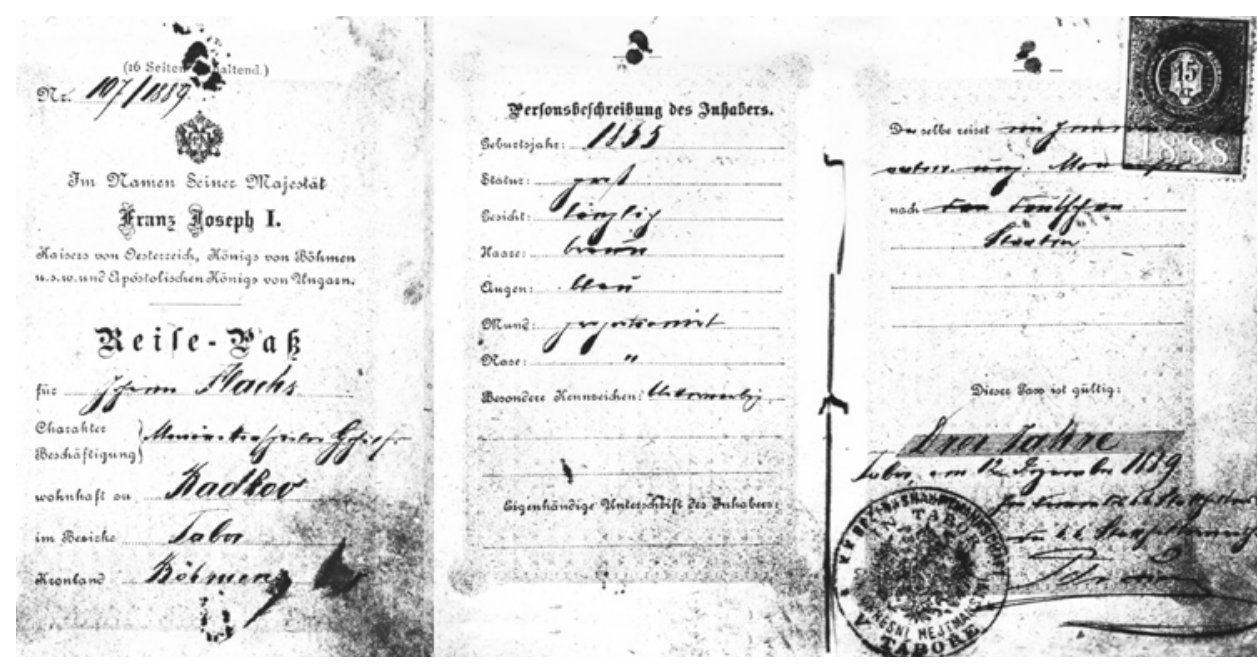

Fig. 1: Passport of Jan Flachs Jr., 1889. (C Collections of MZM.

which dictates its close dependence on conventions. The expressive means of puppet performance co-create the style. In such a case, confirmation of the tradition of which it is an on-going part and the development of this sense of continuity may even become a progressive feature.

The earliest Czech puppeteers, that is those performing in the Czech language, can be traced only with great difficulties given the fragmentary nature of sources and evidence that is often skewed as a result of historical circumstances. Jan Jiří Brát (1724-1805) was one of the first Czech puppeteers, with performance activities undoubtedly confirmed in 1775 and 1796 (DUBSKÁ 2011). In the 1780s, several additional names appear in documents, anticipating the later rise of popular marionette families.

Jaroslav Bartoš was the first in a Czech context to dedicate himself systematically to research into the extensive, though incomplete, archival materials. On the basis of extant marionettist playbills and official requests and licences for the practising of marionette theatre, Bartoš produces a detailed overview of a number of puppeteers and puppet theatre dynasties (BARTOŠ 1963). An enormous growth and branching of marionettist families came in the time of the National Revival. Among the renowned marionettist dynasties were the names of Kopecký, Dubský, Maizner, Vinický, Karfiol, Kludský, Kočka, Fink, Šimek, Maleček, Víd, Kučera, Kaiser, Lagron, Pfleger, Janeček or Nový. Among them were also the Flachs.

Jaroslav Bartoš mentions a certain Ondřej Flachs of Štěchovice in the Prácheň region (a historical county of the Czech kingdom with the town of Písek as its centre) active in Bohemia between 1836 and 1848. He probably had no followers; after his death it was a Jan Lakron of Dřešínek who applied for his concession (licence) in 1856. Another 


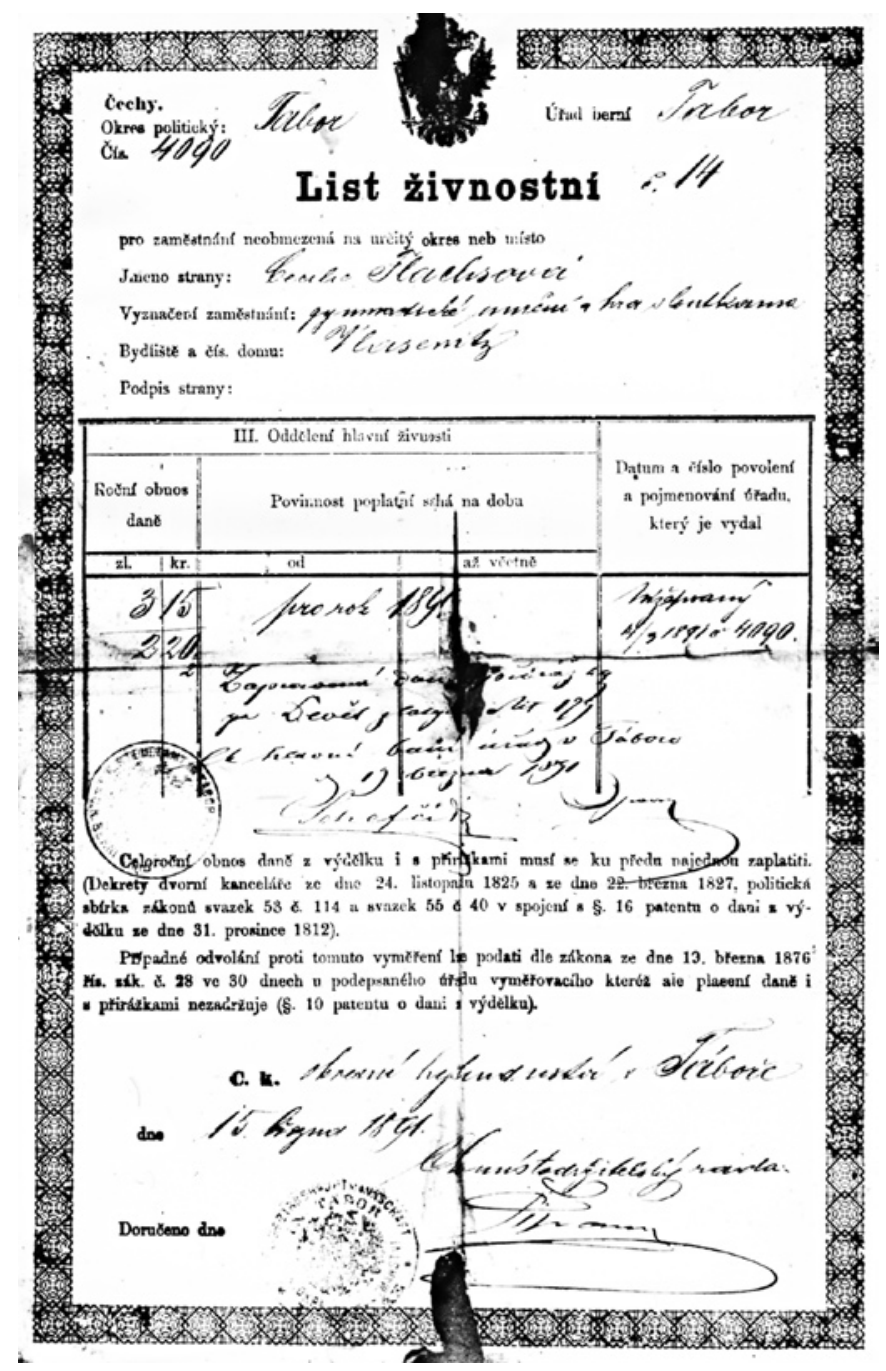

Fig. 2: Trading licence of Cecílie Flachsová (wife of Jan Flachs Senior), 1891.

(c) Collections of MZM.

licence, of 1859, bears the name of an Adam Flachs of Předměřice by Brandýs (BARTOŠ 1963: 161, 166). Jindřich Veselý listed the name of 'Flaks Václav (puppeteering in Moravia, using 'trumalines')' among the marionettists with whom he had been in personal or written contact since 1911 (VESELÝ 1925: 19). One of the legendary puppeteerslegionaries Antonín Kopecký remembered Antonín Flachs as a 'member of the artists' guild' (KOPECKÝ 1933: 30) with whom and with the brothers Matěj and Jindřich they 


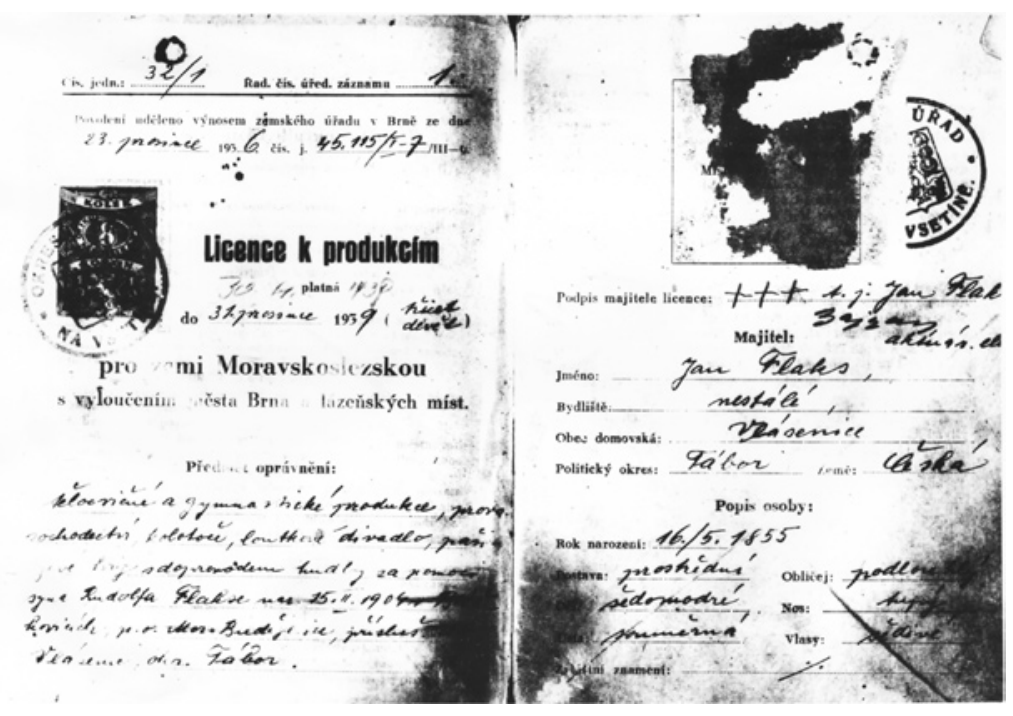

Fig. 3: Production licence of Jan Flachs Jr., 23 December 1936.

(c) Collections of MZM.

had fought on the Italian front and later became members of the Czechoslovak volunteer company in Padula. Elsewhere Kopecký mentions him as a (first) cousin who had used to carve puppets with a pocket knife with them (the Kopeckýs) and with František Tríska in the $2^{\text {nd }}$ Company of the Brigade Machine Gun Brigade on the front on the Altissimo Mountain above Riva and the Lake Garda in August 1918 (KOPECKÝ 1919: 19). Following their capture, they also used to play puppet theatre in a prisoner-of-war camp. Antonín Kopecký speaks of Flachs as a clown who would cast cartwheels and somersaults and performed usual pranks' and as 'a puppet player [who] was masterful with the accordion' (KOPECKÝ 1933: 32, 78). The teacher Václav Nedbal, father of the leading Czech actor, director and pedagogue Miloš Nedbal, recalls in 1912 his participation in the puppet theatre club in Rožmitál under Tremšín some time around 1909 where he used repair and paint stage decorations. At the request of the 'ailing and half-blind Flaks $[s i c]$ ' a performance was to be given there for a small fee, with the marionettes he had lent; there were nine of them and they 'were exceptionally nice, wide and of distinctive carving. After successful performances, Flachs offered his puppets for sale to the amateurs. The deal was eventually made but Nedbal's memoire does not specify which of the Flachs was involved. This small theatre company was later extended by the marionettes of the carved Bohumil Veselý of Př́bram (NEDBAL 1912: 99). Emanuel Veil makes a brief note on the marionette trade of a Josef Flachs whose father came from Blatná in the Strakonice region. Veil met Flachs during a gig in the village of Karlov in 1923 and described his theatre as 'new and very clean [... with] puppets finely carved 


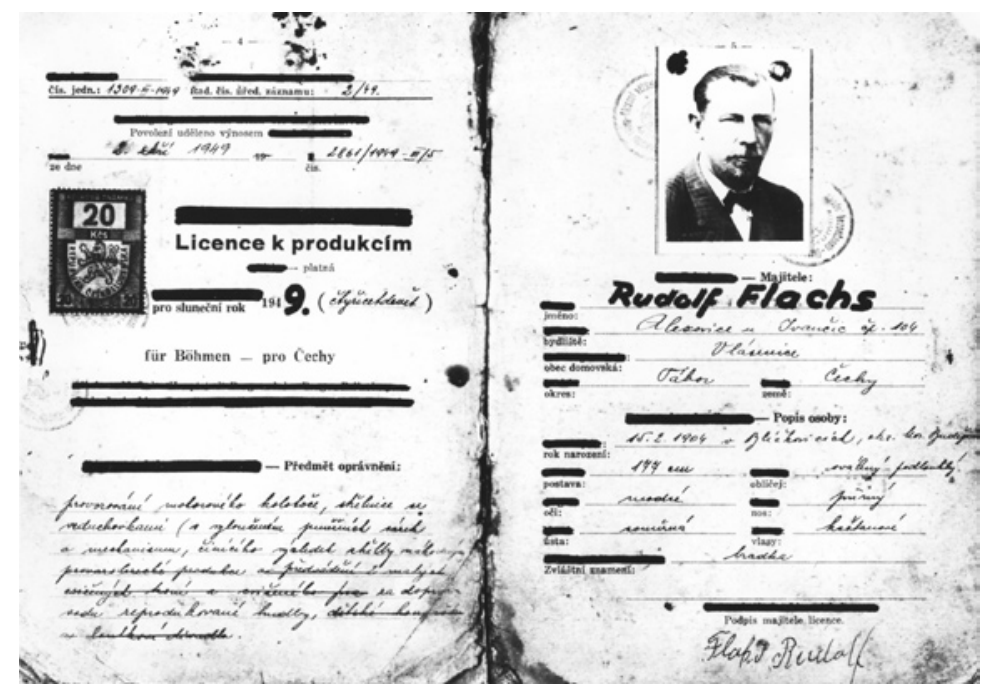

Fig. 4: Production licence of Rudolf Flachs, 2 September 1949.

(C) Collections of MZM.

and clothed. This member of the Flachs family performed predominantly in the south and occasionally in central Bohemia. However, little more than the titles of five plays on Flachs' repertoire and an extensive list of this Flachs's 'jingles' can be learnt (VEIL 1923: 60-1). To this list of active Flachs puppeteers, Alice Dubská adds the names of Hynek Flachs from Spálené Porričí (mid-nineteenth century), and Jan and Emanuel Flachs in the context of the 1920s (DUBSKÁ 2010: 368).

In the following text, my focus will be on the part of the dynasty ending its activities in Moravia - a branch of the family tree with three Jans. The only facts known of the earliest Jan Flachs, here called 'Jan Flachs the Eldest', are that he was a subject in the borough of Vlásenice (Wlasenitz), had a wife named Cecílie and that he fathered six children. The council of Vlásenice issued a licence for him to perform in that borough, and in the villages belonging to Vlásenice. The second Jan Flachs, who is recorded as Jan Johann Flachs, is noted here as 'Jan Johann Flachs Sr'. and the third as 'Jan Johann Flachs Jr'. (see Figs. 5, 6 and 7). The name of Flachs was often corrupted as Flax, Flaks and so on. In the family of Rudolf Flachs, a number of valuable documents have survived that confirm the puppetry activities of three generations of Flachs. Given that marionettists almost never stored documentation that was no longer valid, these extant materials are factually unique sources. Among the most valuable are the travel passport of Emilie Flachsová (Toužilová) of 5 September 1888, the travel passport of Johann Flachs Jr. of 12 December 1889 (Fig. 1), the trade licence of Cecílie Flachsová of 15 March 1891 (Fig. 2), the travel passport of Johann Flachs Jr. of 25 March 1911, the performance licence for Jan Flachs Jr. of 31 December 1939 (Fig. 3), and the performance licence for Rudolf Flachs of 2 September 1949 (Fig. 4). 
The early activities of Jan Flachs the Eldest (?-ca.1856), probably the 'patriarch' of the later extensive family, are documented by the oldest surviving document: a request for licensing puppets and juggling, submitted to the county council in Tábor and turned down by the Gubernium on 2 June 1828. A concession for 'puppets and juggling' for Tábor, Budějovice, Prácheň and Beroun was eventually granted him on 12 December 1831; this was regularly renewed until 1851. After Flachs's death, the licence for puppets and gymnastics was held by his wife Cecílie Flachsová; this licence was issued for the period 1856-1860 and covered the counties of Tábor, Budějovice, Plzeň and finally the whole of Bohemia (BARTOŠ 1963: 160-1). However, it is uncertain if this information, given by Jaroslav Bartoš, is not confused, since Cecílie (Caecilia), née Holzknechtová, was certainly the wife of Jan Flachs Sr. The family collection holds her Trade licence of 1891 (Fig. 2) that denotes his trade as 'gymnastic arts and playing with puppets' (gymnastické umění a hra s loutkama).

The son, Jan Flachs Sr. (ca.1800-?) had his own trade licence, documented on 19 March 1838; he was granted a puppetry concession for the same territory as his father, that is, four counties, and for the whole of Bohemia from 1855 until at least October 1859 (BARTOŠ 1963: 160). He was allegedly the cousin of Antonín Kopecký; however, it is unclear which of the known Antonín Kopeckýs is meant. The pedigree of the Kopecký family, as made by Jindřich Veselý, ascertains only the fact that Jan Kopecký (born 1804) adopted two children born to his third wife (née Kučerová) and that his stepdaughter, Katyna Kabourková, married one of the Flachs family.

The third of the generation, Jan (Johann) Flachs Jr. (1855-ca.1940) (Fig. 7), also registered in Vlásenice in the county of Tábor, is presented in the register on the birth of his son Rudolf as a 'Marionetten-Spielbesitzer', that is as a 'marionette theatre (play) owner'. The extant sources give his name either as Jan, or Johann; on a request of 1898, he is signed as 'Johann', while on a trade licence of 1939 (Fig. 3) he appears as 'Jan'. In the travel passport of 1911 the son is presented among the co-travellers as 'Jan-Johann'. The register gives that he was the son of Johann Flachs and Caecilia Holzknecht (daughter of the marionettist František Holzknecht of Písek); his wife was Emilie Flachsová, born on 18 April 1857 (Figs. 5 and 6), the legitimate daughter of František Toušl, theatre director in Církvice and his wife Kristina, née Vaňková. Johann Flachs's date of birth, given here as 28 April 1855, contradicts the date stated on Johann's performance licence of 1939, which reads 16 May 1855. His wife Emilie's date of birth also does not match: her travel passport of 1888, issued to 'Emilie Toušel', gives 1862 rather than 1857. The search for the dates of the three Jan Flachs' in the registers of births, marriages and deaths for Vlásenice, Bohutín, Radkov, Kadov and Modřice (near Brno) has so far been unsuccessful.

Jan Flachs Jr. was married to Emilie in the church in Bohutín (county of Tábor) on 11 February 1890. Their residence was unstable, later stating it as Radkov, or even Kadov (not specifying whether this was the Kadov near Strakonice, or the Kadov near Znojmo); eventually they settled in Moravia, in Modřice (near Brno). They had five 


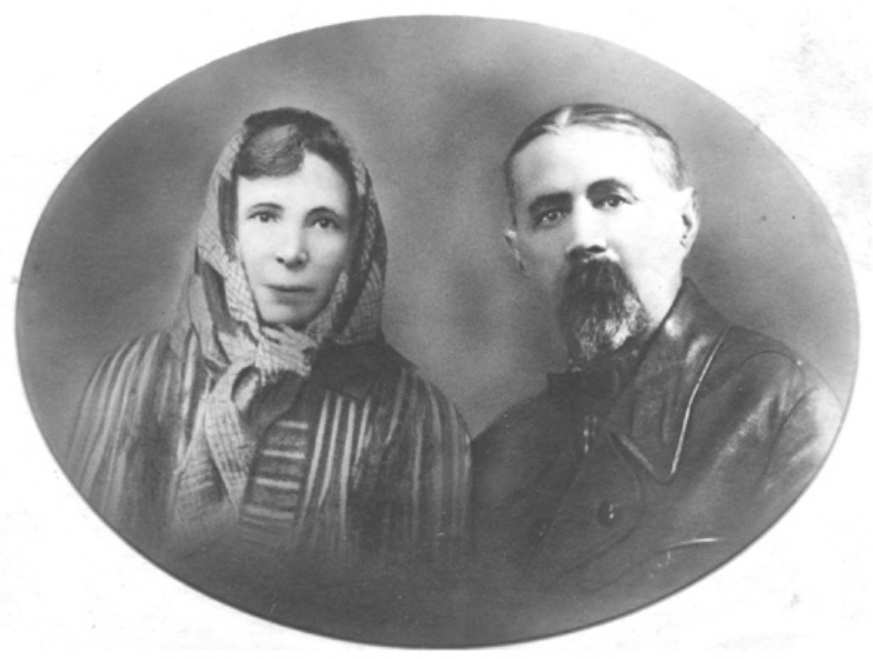

Fig. 5: Jan Flachs Jr. with his wife Emilie. (c) Collections of MZM.

children: Josef (1881), Jan (1891), Emilie (1893; married to marionettist Jan Vald of Drouhá Brtnice near Jihlava, resident in Dobelice near Moravský Krumlov), Vilém (1900 (Fig. 6)) and Rudolf (1904 (photos Figs. 8, 9 and 10)). Josef and Rudolf continued in the family tradition of marionette theatre. Jan Flachs Jr. had four brothers; none of them allegedly practised puppetry. Brother Václav Flachs (born 1864) became the owner of Scheich's theatre in 1915 but he never performed in it himself. Jindrich Veselý probably mentioned Václav Flachs as a marionettist due to his 'roots' (in his youth he surely toured with his father). When he became independent, he gave up puppet theatre and had a trade in fairground attractions - American swings, a merrygo-round and a shooting range.

A valuable testimony of Jan Flachs Jr. was provided by teacher František Nevoral in the journal Loutkár in 1922, based on his own experience of meeting Flachs and on documents that Jan Flachs had lent him to peruse. These were: a passport (No. 93) of 25 November 1911, issued by the county council in Tábor for three years, later extended by another three years on 8 May 1914, and again for three years on 17 July 1917, this time by the county council in Moravský Krumlov (partly survived in the collections of MZM); and another passport of 22 February 1921, issued by the Moravian Regency Office in Brno (NEVORAL 1922: 96, 110). Nevoral's report very likely refers to Flachs' gig in Dolní Kounice in August 1921. The information given here suggest that the 'principal' travelled with his family - wife Emilie, daughter Emilie and sons Jan, Vilém and Rudolf. The eldest son Josef probably already had his own trade by then. The family toured on four wagons, one of them carrying the dismantled merry-go-round. The theatre consisted of 25 puppets, some $80 \mathrm{~cm}$ in height. They travelled with five horses, a goat and 


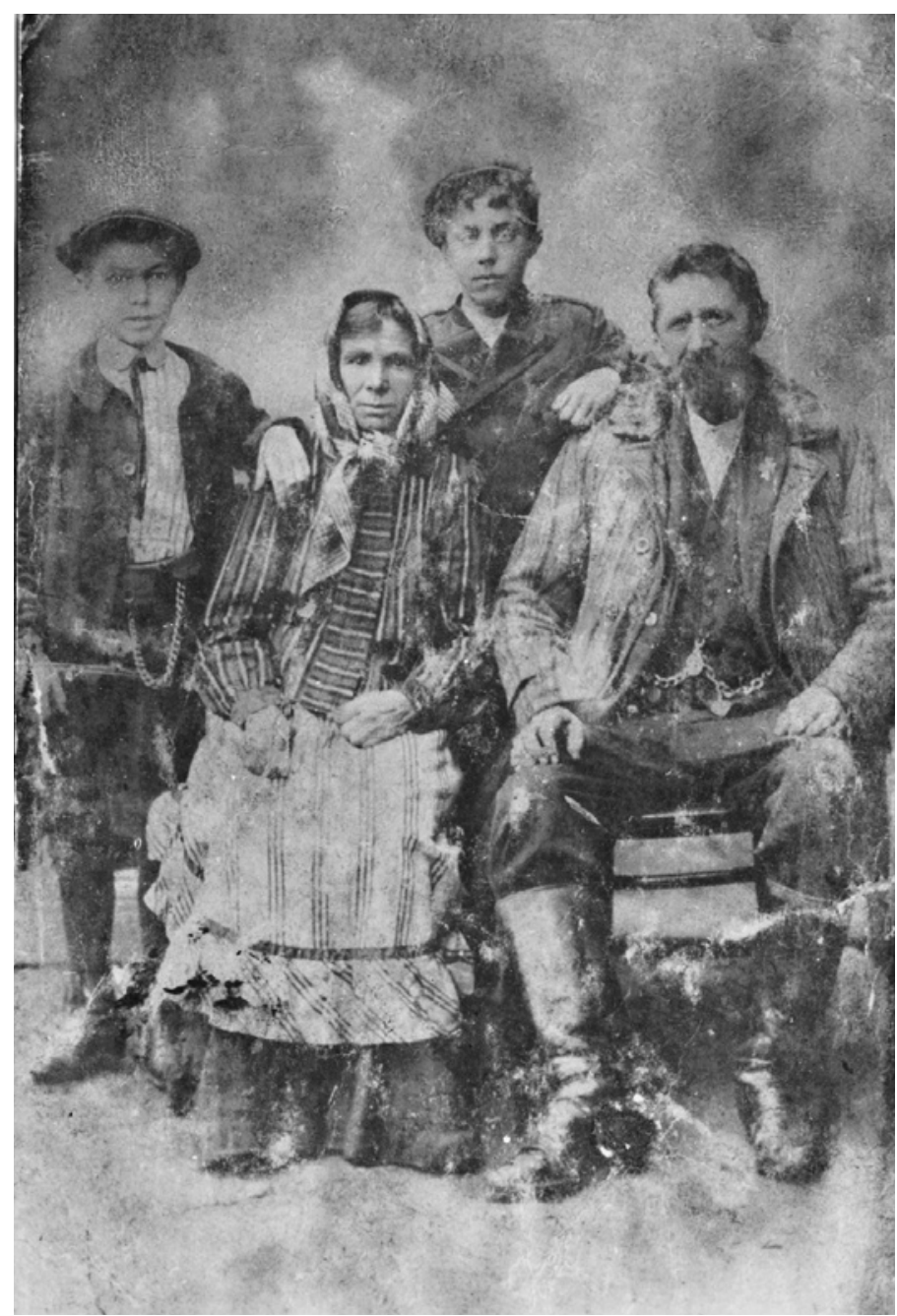

Fig. 6: Jan Flachs Jr. with his wife Emilie and their sons Rudolf (left) and Vilém, ca.1915. ๑ Collections of MZM.

two pigs. As for the wagons, as the son Rudolf recollects later, these were the so-called pakovák (packing wagon), that carried puppets and the theatre, covered pod plachtou (under tarpaulin), then a larger caravan for the parents, called vostavák (the lodging wagon), a smaller caravan for children, and a wagon with the merry-go-round. In the passport of February 1921, Flachs had a licence:

ku provozování kolotoče, loutkového divadla a ku předvádění pašijových her za doprovodu hudby na Moravě, vyjma v Brně a v Olomouci až do konce února 1922. 


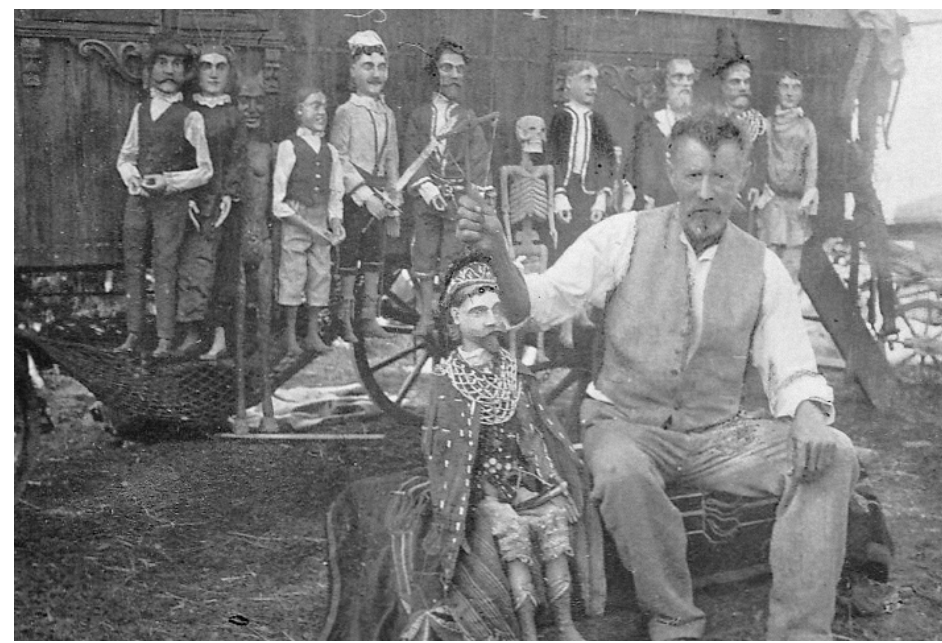

Fig. 7: Jan Flachs Jr. on tour, ca.1923. (C) Collections of MLK.

[to operate a merry-go-round, a puppet theatre and to perform passion plays with music in Moravia, with the exception of Brno and Olomouc, until the end of February 1922.]

He gave deposition himself that he had recently been only touring Moravia - in the counties of Moravský Krumlov, Znojmo, Moravské Budějovice, Hustopeče, Tišnov, Brno, Kyjov and Vyškov. In his youth, he allegedly practised gymnastics and rope-dancing, touring Germany, Silesia, Bohemia, Moravia and Hungary.

Unfortunately, Nevoral comments on Flachs's productions only very briefly although he had seen three performances. He reports that the theatre was performed by the father (the principal) and a son (his name was not given, only that he was a war invalid); both of them delivered their roles from memory, but the son was unable to compete with the father's art. The performances were cried by all three sons jointly, in rounds around the town, accompanied by drumbeating.

Flachs recalled these titles in their repertoire:

- Mučení křestanů v turecké zemi (The Tortures of Christians in the Turkish Land)

- Dobytí hradu bělohorského (The Siege of the Castle of Bílá Hora)

- Návrat legionáre (The Legionary’s Return)

- Nalezené dítě (A Foundling)

- Veselý švec neboli prohandlování zlé ženy (A Merry Shoemaker, or Bartering an Evil Wife)

- Doktor Faust z Majlandu (Doctor Faust of Milan)

- Loupežníci na Chlumu (The Highwaymen of Chlum; based on a 1815 melodramatic play by Jan Nepomuk Štěpánek, in turn based on Heinrich C. Kuno’s 1814 German play Die Räuber auf Maria-Kulm) 
- Bezhlavý rytír (The Headless Knight)

- Herkules (Hercules)

- Hejtman Kovařík, viddce vrahü (Colonel Kovařík, the Leader of the Murderers)

- Švejdové na Moravě neb Dobytí města Vyškova (The Swedes in Moravia, or the Siege of the Town of Vyškov)

- Tři ženiši a jedna nevěsta (Three Grooms and One Bride)

- Jiřík Poděbradský (King Jiří of Poděbrady, probably based on Vítězslav Hálek’s 1874 play or on Věnceslav Durych's 1884 play about this Hussite king)

- Žižkova smrt (The Death of Žižka, probably based on Josef Jiří Kolár's 1851 drama of the Hussite general Jan Žižka, or on Jan Nepomuk Laštovka’s play)

- Poslední katovo dílo na Točníku (The Executioner's Last Act on Točník Castle; probably based on Václav Kliment Klicpera’s 1828 romantic short story Točník)

- Krčma v lese (An Inn in the Forest)

- Život sv. Jiři (The Life of St George)

- Děj utrpení a smrti sv. Jenovefy (The History of the Suffering and Death of St Genevieve)

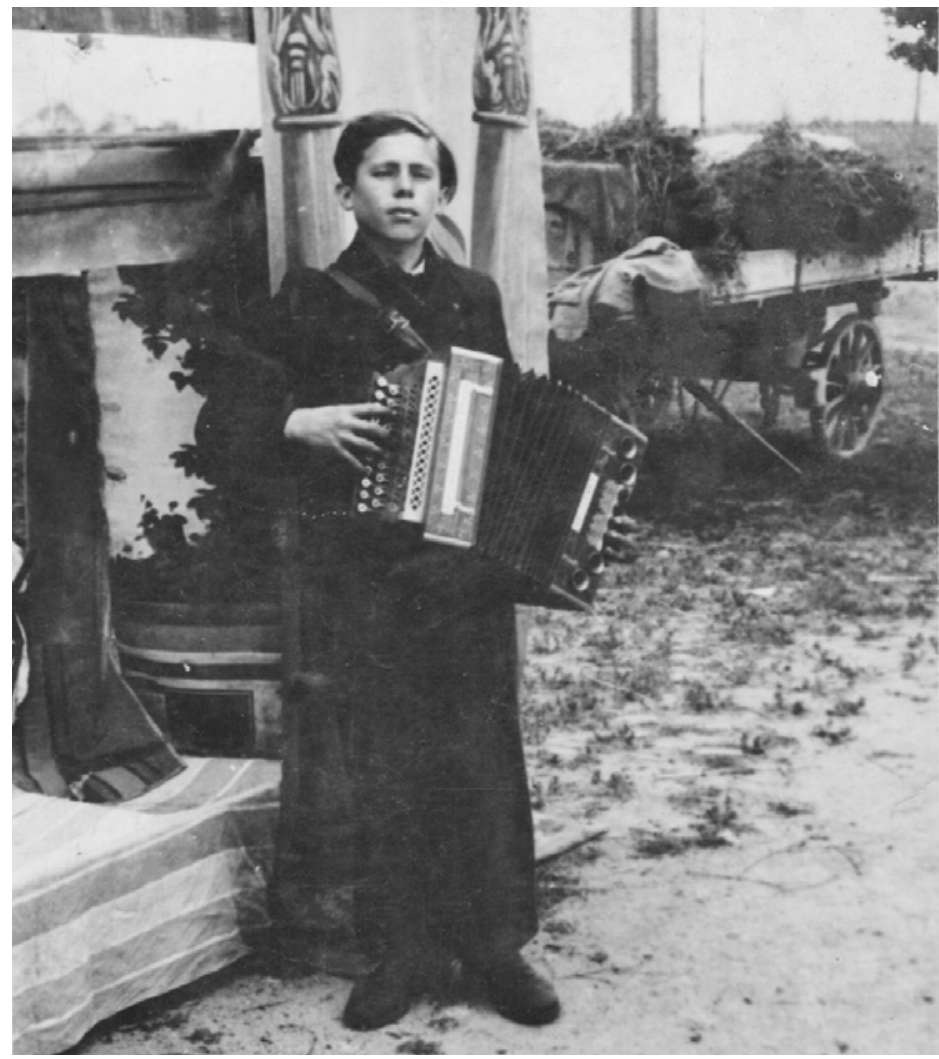

Fig. 8: Rudolf Flachs, $c a .1920$. () Collections of MZM. 
- Žid Šiloch (The Jew Shilokh, probably based on František Vodsedálek's 1815 adaptation of a prose version of Shakespeare's The Merchant of Venice)

- Jan za chrta dán (A Son for a Greyhound; a legend probably based on Václav Kliment Klicpera's 1828 play)

- Zdeněk Zásmucký (Zdeněk of Zásmuk; a legend of the saviour army of the mountain of Blaník, probably based on Alois Rada’s early 1900s puppet play)

- Čert a Káča (The Devil and Káča; a fairy tale)

- Rezedie

- Pražský Kleveta (The Gossiping Man of Prague)

- Mlynár a jeho díté (The Miller and his Child; probably based on Ernst Raupach’s 1830 melodramatic play Der Müller und sein Kind)

- Loupežníci v českých lesích (The Highwaymen in the Bohemian Woods)

- Dobytíhradu Rábí(The Siege of Rábí Castle; probably based on Jan Nepomuk Laštovka’s play on Hussite history)

- Hostinec u silnice (An Inn on the Road)

- Mladý Liandr (The Young Liandr)

- Nocleh v lese neb Dvě slova (A lodging in the Woods, or Two Words)

- Pálení Jana Husa (The Burning of John Hus; probably based on Josef Kajetán Tyls 1848 play Jan Hus)

- Břetislav a Jitka (Břetislav and Jitka - a Czech legend)

- Oldřich a Božena (Oldřich and Božena - a Czech legend)

Principally this is a standard repertory as performed by most marionettists of the early 1900s. There are reminiscences of original titles from the international marionette repertoire, as well as younger plays of more specifically Czech origin, popular with late nineteenth-century puppeteers, especially those plays which were adaptations of works by Václav Thám (1765-ca.1816), Simeon Karel Macháček (1799-1846), Václav Kliment Klicpera (1792-1859), Josef Jiří Kolár (1812-1896), Jan Nepomuk Laštovka (1824-1877) or Alois Rada (1868-1951). Undoubtedly, these were also plays paraphrased by the trio of author-humourists Heřman Přerhof, Eduard Just and Josef Richard Vilímek in their controversial edition of Komedie a hry Matěje Kopeckého (The Comedies and Plays of Matěj Kopecký), published in two volumes in Prague in 1862. Only two of the listed titles cannot be identified by name, Rezedie and Loupežníci v českých zemích. If Flachs really performed all the given titles, he can be counted amongst the more agile and expedient marionettists.

There are only a few valuable documents of the later years of Jan Flachs Jr.; these complement the scattered information of the marionettists' activities. So in the 'Licence to produce in the Moravian-Silesian land with the exception of Brno and the spa resorts' issued to Jan Flachs Jr. by the county council in Vsetín on 13 January 1937 (valid till 31 December 1939), the subject of the licence is given as: 


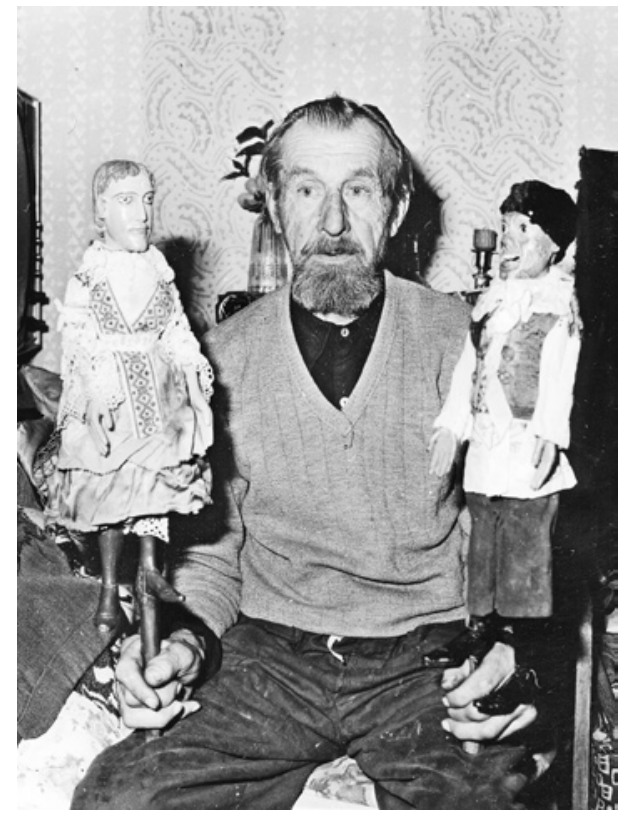

Fig. 9: Rudolf Flachs with his puppets, the so-called mikrlata, 1983.

(c) Collections of MZM. Photo (c) Jaroslav Blecha.

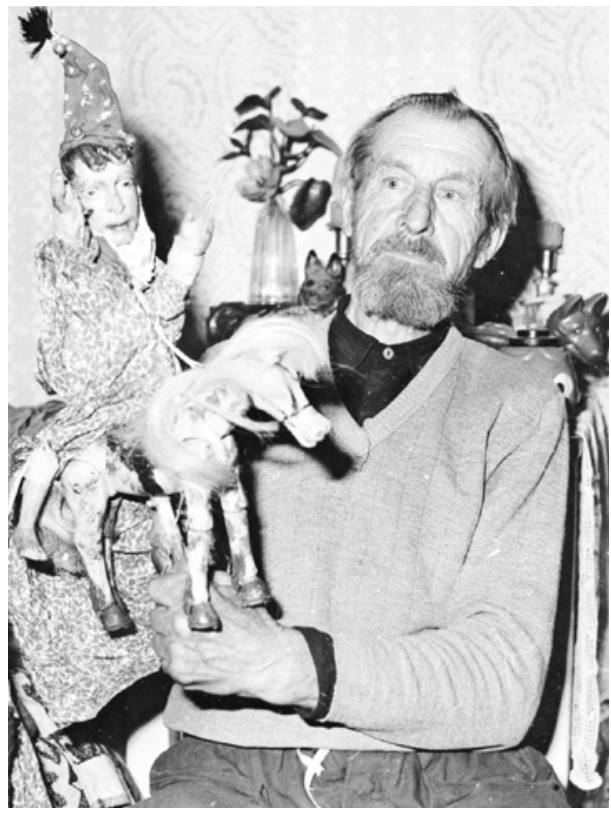

Fig. 10: Rudolf Flachs with his puppets, the so-called mikrle (a horse) and a glove puppet, 1983.

(c) Collections of MZM. Photo (c) Jaroslav Blecha.

Physical exercise and gymnastic productions, rope-dancing, merry-go-rounds, puppet theatre, passion plays with the accompaniment of music with the help of son Rudolf Flachs $[\ldots]$.

The description of the holder is also of interest:

medium build, oblong face, grey-blue eyes, snub nose, symmetrical mouth, greyish hair.

It is remarkable that the holder's residence is given as 'unstable' with the home borough of Vlásenice. Flachs signed with three crosses; however, this was not due to his illiteracy but because, according to his son Rudolf's testimony, due to advanced health his hands were shaking and he could not write. In reality he had mastered both Czech and German in writing and his literacy can be testified by a manuscript of 6 January 1898; this is a German request submitted to the county council in Těšín (Bezirkshauptmannshaft Teschen).

A passport torso from 1937-1938 has survived bearing official records known in the marionettists' jargon as 'vidýr' - from the Latin vidi ('I have seen', from the verb video); Flachs's passport reads 'viděno' (meaning 'seen'), 'viděl' ('has seen'), 'vidováno' ('vidied')). The passport documents the following as places in which it was 'vidi-ed' (seen by local authorities): 


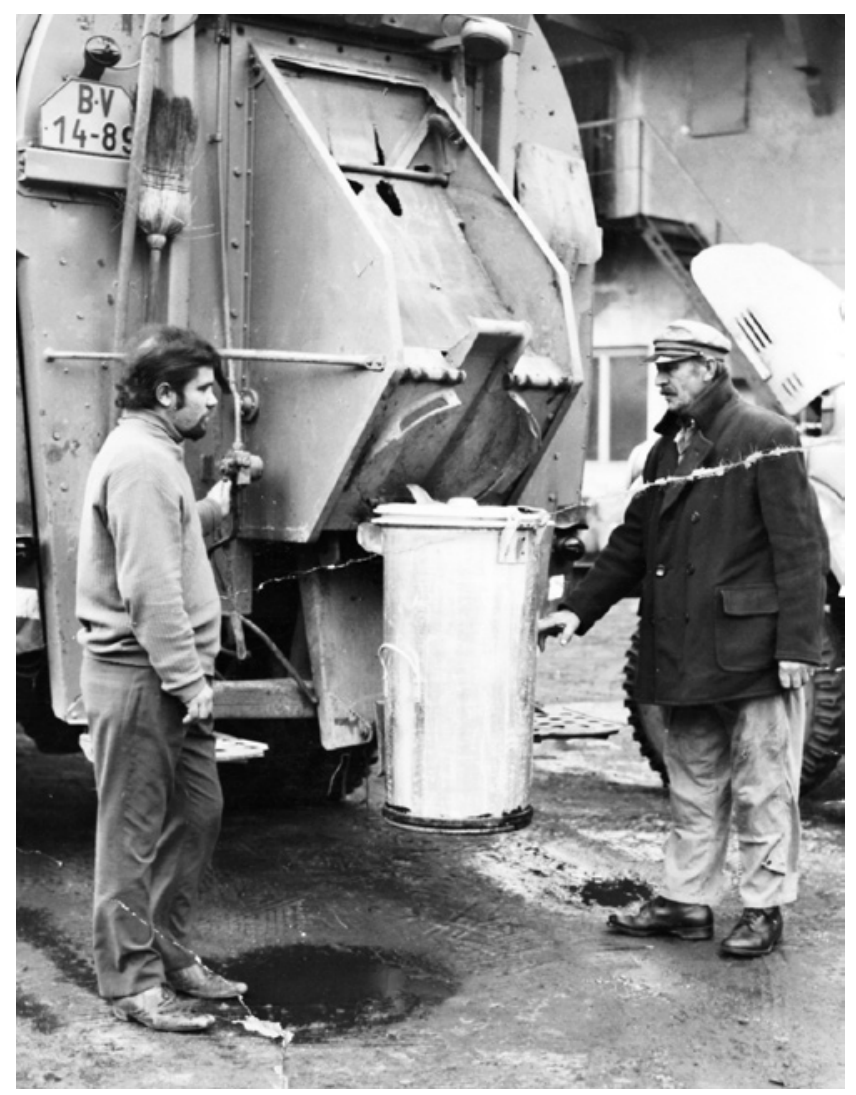

Fig. 11: Rudolf Flachs as a rubbish collector. (C) Collections of MZM.

Vsetín, Hoštálková, Holešov, Prusinovice, Ludslavice, Kroměříž, Střižovice, Trávník u Kroměříže, Chropyně, Žářice, Přerov, Ivaň, Kunovice, Petřice, Křenovice, Měrůtky, Hradisko, Skaštice, Dřevohoštice, Nahošovice, Tučín, Henčlov, Prostějov, Střížov, Brno, Moravský Krumlov, Džbánice, Skalice, Znojmo, Višňové, Jinošov, Velké Meziříčí, Uhřínov, Svatoslav, Červená Lhota, Číhalín, Petrovice, Třebíč, Dačice, Krahulov, Pěčín, Šašovice, Moravské Budějovice, Ratibořice, Jaroměřice nad Rokytnou, Dřešovice, Častohostice, Šach, Radlice, Studená, Horní Olešná.

The very list testifies to the extensive touring that the elderly marionettist Jan Flachs Jr. was undertaking.

Among the last members of the Flachs puppeteer dynasty who tried to maintain the tradition of travelling Czech marionette theatre until the middle of the twentieth century were two of Jan Flachs Jr's sons. The eldest, Josef (born 1881), settled in Šmice near Uherský Brod, and in his old age moved to Kunovice. It is unknown when he became 
independent; but in 1921, he was no longer travelling with his father. However, he did not practise marionette theatre for long; instead he made a living of rope-dancing and in the winter he would perform 'live theatre' with his family. His wife was Antonie Hněvkovská (born 1877) and they had nine children - six daughters and three sons. One of the daughters, Vlasta (married Nová), recalls that they 'would give entertainment after the production: daddy on the hurdy-gurdy, mum on the triangle and sister on the drums'.

The youngest son Rudolf Flachs (1904-1984 (Figs. 6, 8, 9 and 10)), registered in Břeclav, practised marionette theatre the most. For a long time he had travelled with his father, and he took over the trade in the early 1940s. During the first half of the twentieth century, professional marionette theatre was perceived as a certain anachronism; nevertheless, it still represented a trustworthy testimony of a significant period of Czech puppetry history. Rudolf Flachs, alongside other like marionettists such as Václav Kopecký of Brno, embodied such a testimony with his marionette theatre. His authentic memoires conflate the responses to the heyday of his father's theatre with his own later marionettist practice. He claims the 'gigs' would take up to a year, depending on how far they would travel. They toured both Bohemia and Moravia and always had two performance licences. As has been mentioned, they were not allowed to give productions in Brno and in spa resorts. They had different wagons - larger ones for the summer, but took smaller carriages for the 'bigger circuit' so that the horses could draw them even through snow. At venues they generally stabled their horses in exchange for theatre tickets. The theatre - or at least its torso, including parts of the decorations - has survived in the collections of the MZM. It had a proscenium arch and a curtain painted by the craftsman painter Jan Vysekal of Kutná Hora; it showed the Hussite general Jan Žižka and the Hussite priest and general Prokop Holý on the sides, a Czech lion was located at the top, and the legendary figures of Bretislav and Jitka may be seen on the curtain (Fig. 12). For lighting, the Flachs used petroleum lamps first, later carbide lamps. Rudolf Flachs confirmed that their repertoire was principally identical to that listed by František Nevoral (see above). He added remarkable information on the Jenovéfa play; they used to perform it 'in two parts' over two nights. One of Josef Flachs's daughters, Marie (married Berousková), confirmed this information. ${ }^{2}$ She recited the entire play (in both 'parts') from memory, as it had been played by the Flachs; a sound recording of this reconstructive performance is deposited in the MZM. Rudolf Flachs gave only few details on actual performance practice. On the declamation:

Dneska by děti ani té řeči nerozuměly. Byla to pravá čeština, kdo by chtěl dneska vystupovat, to by si musel dát pozor.

[Today, children wouldn't even understand the speech. It was true Czech. Anyone who would like to perform it today, would have to be wary.]

2 In this essay I am referring to written and sound recorded memoires of Marie Berousková, Rudolf Flachs, Bohumil Kočka, Emilie Kočková and Vlasta Nová, deposited in the collections of the MZM (Moravské zemské muzeum). 
On the encores after the main play:

Děda vymýšlel veselý frašky - ke konci pro zasmání. Po pohádce čineláři, pak ten dlouhej [černoušci s činely a tzv. dupák], pak jeden se šavlema a nakonec přijel Kašpárek s koníkem a končilo se.

[The old man came up with merry farces - for laughter at the end. After the fairy tale the cymbal-men, then the long one [these were two black men with cymbals and the so-called stamping man; see Fig. 25], then one with sabres and, finally, Kašpárek with a horse - and that was the end.]

The late practice of Rudolf Flachs shows signs of transformation in puppet (or travelling) theatre, namely in aiming at providing child audiences with an adequate repertoire. Besides marionettes that he used to perform for adults, Rudolf Flachs also acquired smaller glove puppets and rod puppets, called mikrlata, which he used to perform fairy tales in schools. Several references survive from the late 1950s from primary schools where Rudolf Flachs performed glove puppet fairy tales Pyšná princezna (The Proud Princess) and O Kašpárkovi a nehodném princi (Kašpárek and the Naughty Prince). The former is a fairy tale The Shepherd or the Proud Princess by B. Azur; the latter cannot be identified by its title.

Just like many other traditional marionettists, Rudolf Flachs and his children were negatively affected by post-war political changes, eventually leading to the perishing of travelling marionette theatre. In May 1945, all theatre was nationalised and put under state control, which effectively meant the end of marionettist trade licences and theatre entrepreneurship based on concessions. The Theatre Law of 1948 became the political directive that codified puppetry as a co-equal theatre form and cultural asset for whose care the state was responsible. In spite of that, as late as 1949, Rudolf Flachs received a licence 'for productions valid for the solar year of 1949 für Böhmen - for Bohemia' (Fig. 4), which lists the licensing of:

provozování motorového kolotoče, střelnice se vzduchovkami (s vyloučením peněžních sázek a mechanismu, činícího výsledek střelby náhodným), provazochodecké produkce a předvádění malých cvičených koní a cvičeného psa za doprovodu reprodukované hudby, dětské houpačky a loutkové divadlo.

[operating a motored merry-go-around, a shooting range with air rifles (excluding monetary betting and mechanisms that make the result of shooting random), rope-dancing productions, the exhibition of small trained horses and a trained dog to the accompaniment of reproduced music, children's swings and a puppet theatre.]

The licence also gives the 'residence in Alexovice near Ivančice, home borough in Vlásenice' and observes that ' $[\mathrm{t}]$ he enterprise perambulates with wife Cecilie, children Vlasta, Josef, Emilie and Františka'. 


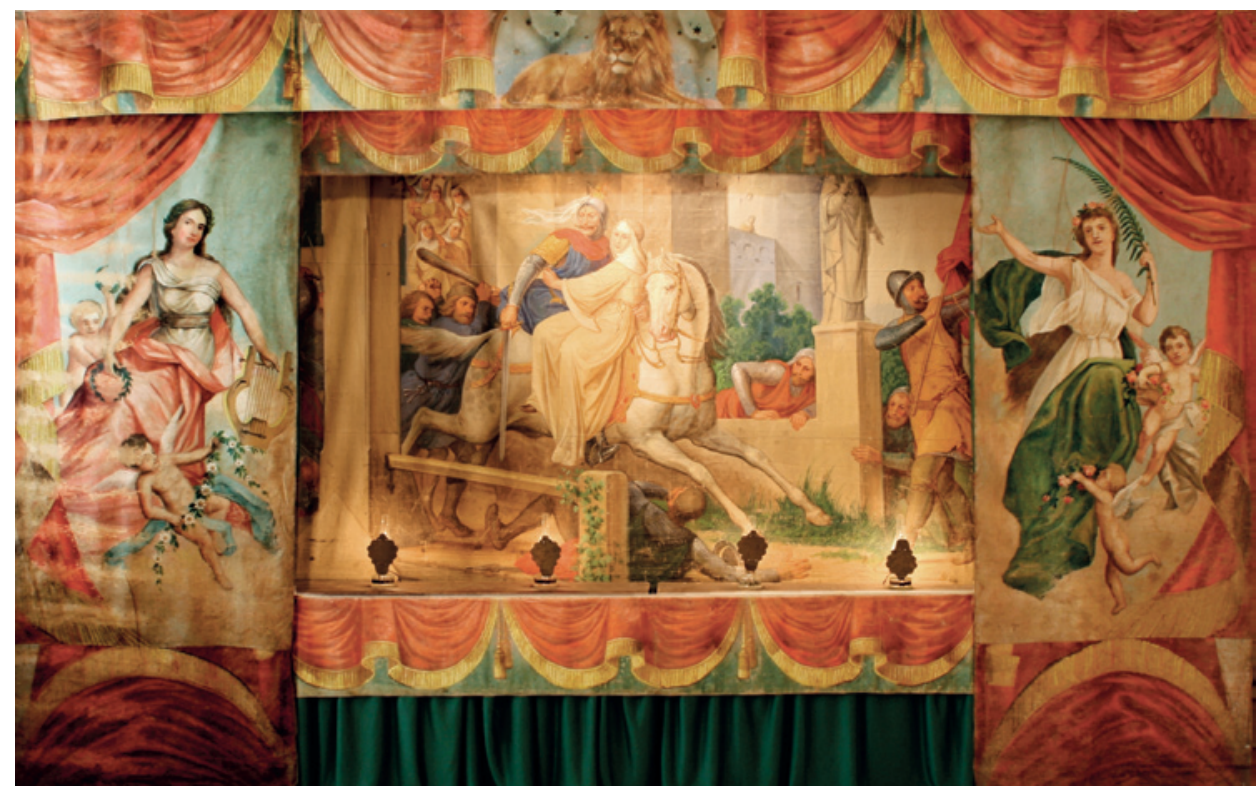

Fig. 12: The curtain of the theatre of Jan Flachs Jr.. 'Břetislav and Jitka' with the upper portal flat. Painted by Jan Vysekal of Kutná Hora, late $19^{\text {th }}$ century. $340 \times 170 \mathrm{~cm}$.

(c) Collections of MZM. Photo (c) Jaroslav Blecha.

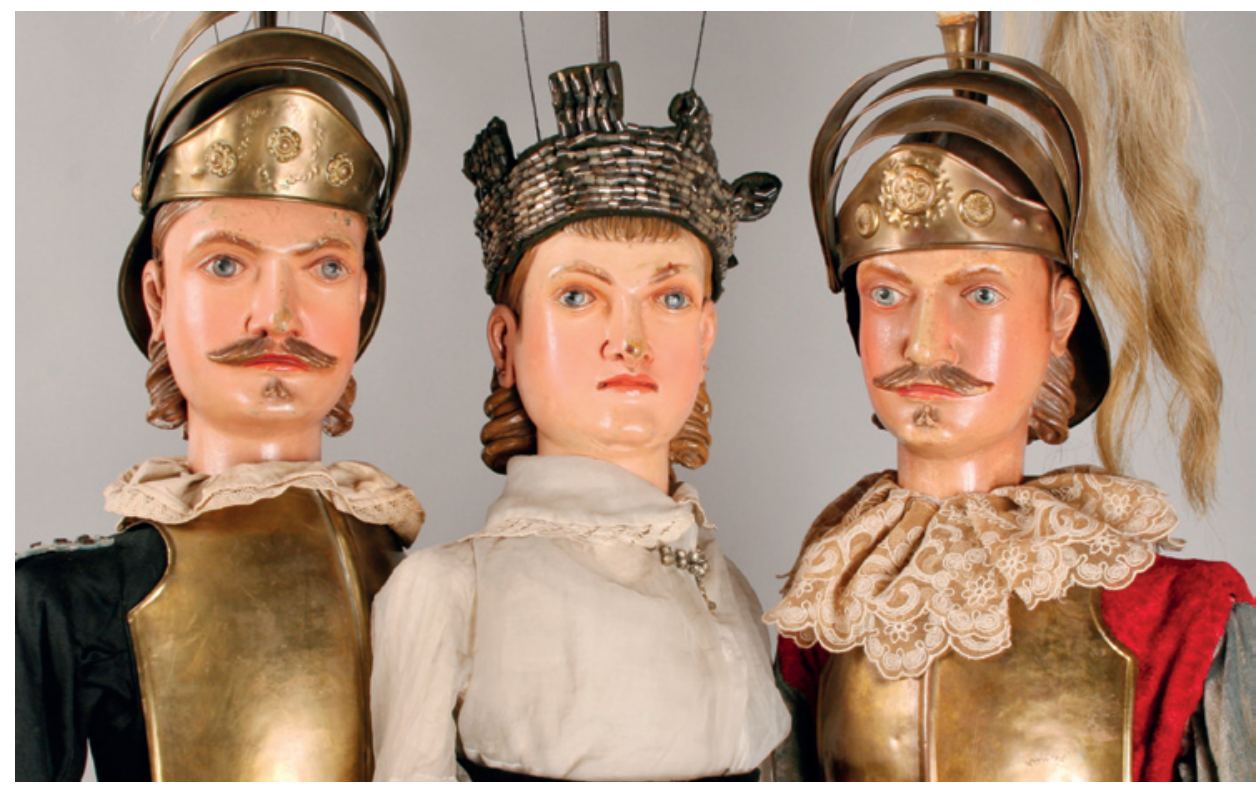

Fig. 13: The largest marionettes of the Flachs family from the exclusive set of the so-called 'Berouseks'. (Note the reiterating type of the young aristocrat.) (c) Collections of MZM. Photo (c) Jaroslav Blecha. 


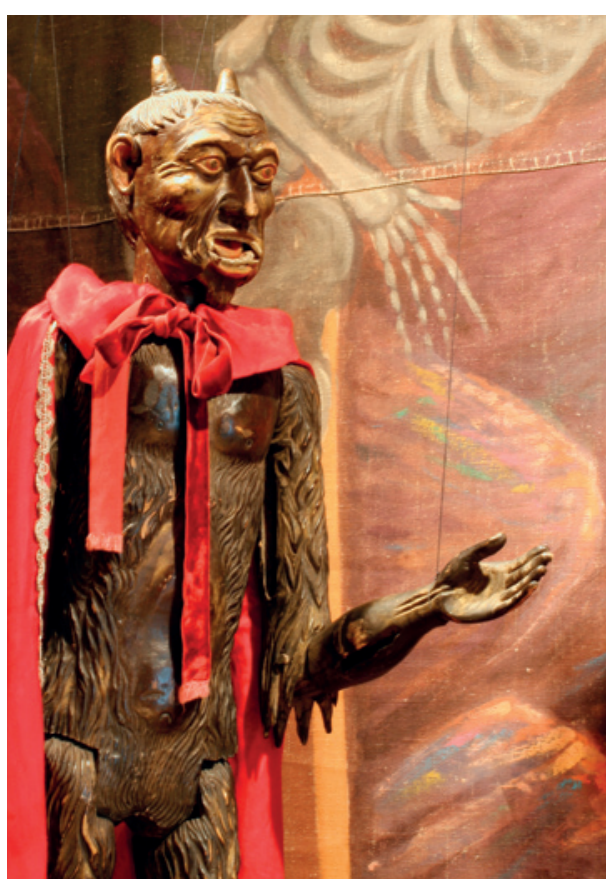

Fig. 14: Marionette of the Devil from the Flachs family exclusive set of the 'Berouseks'.

(C) Collections of MZM. Photo (C) Jaroslav Blecha.

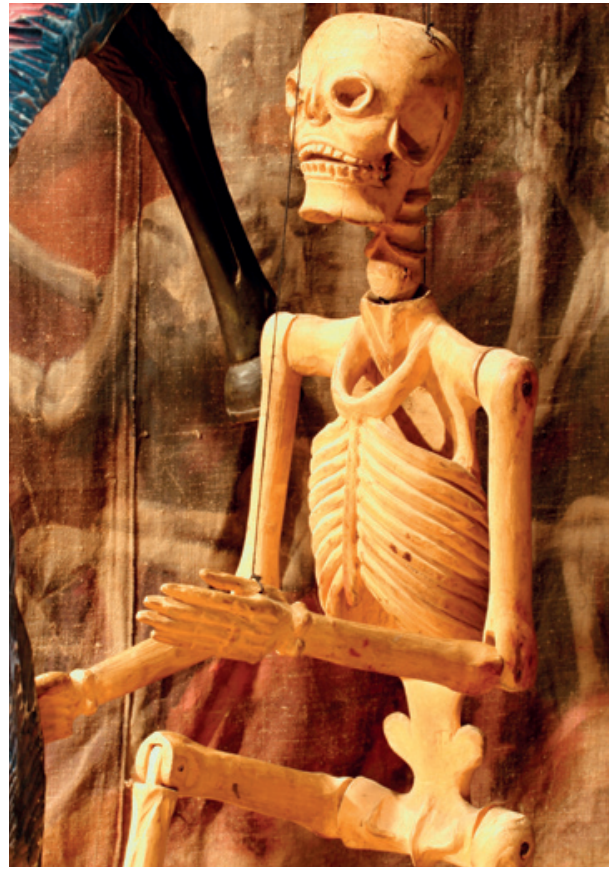

Fig. 15: Marionette of Death from the Flachs family exclusive set of the 'Berouseks'. (C) Collections of MZM. Photo (c) Jaroslav Blecha.

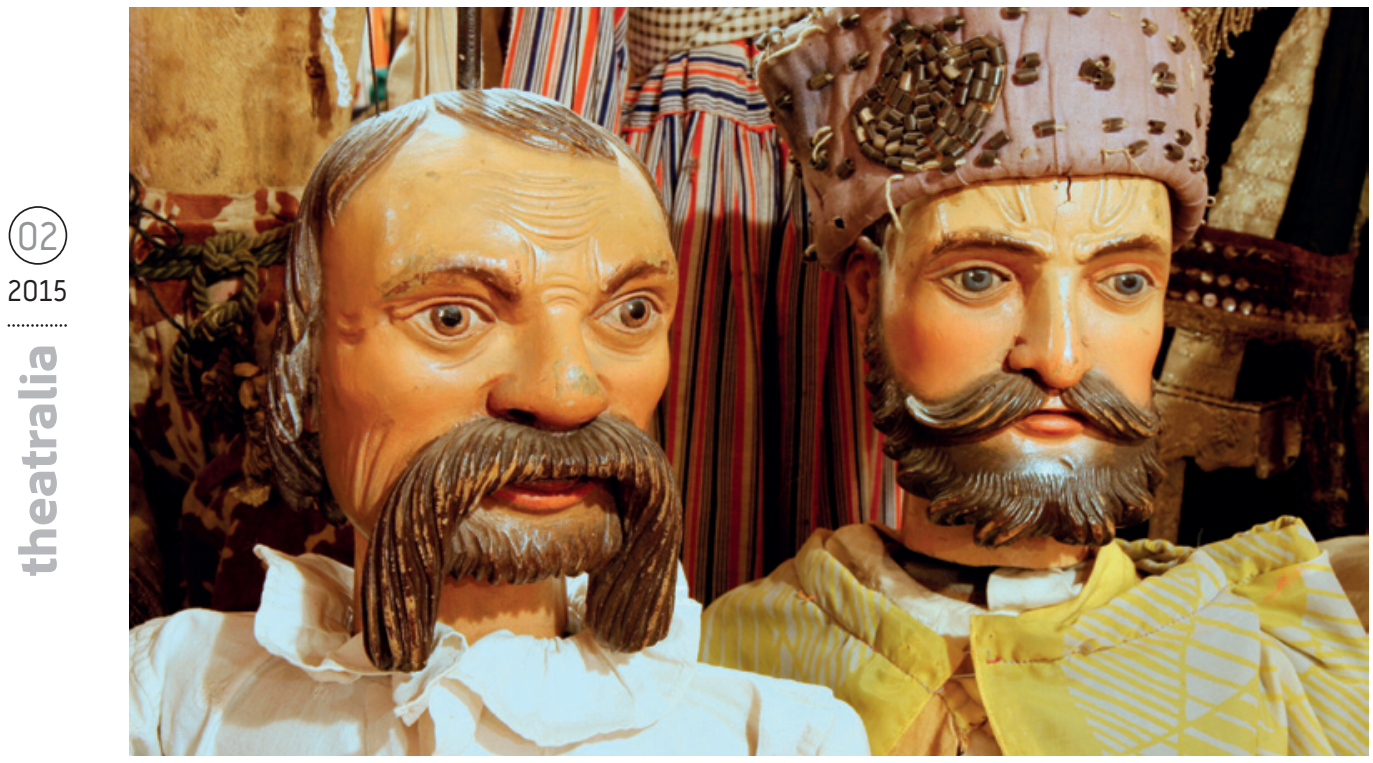

Fig. 16: Marionettes of the Peasant and the Count from the Flachs family exclusive set of the 'Berouseks'. (C) Collections of MZM. Photo (c) Jaroslav Blecha. 
The incomplete extant records of 'vidi-ing' for individual counties in 1949-1951 list the permits for Moravsky Krumlov, Mikulov with the exception of the borderland villages and the county town, Židlochovice, Břeclav, Hustopeče, the counties of Brno (outside the city of Brno), Jihlava, Olomouc, Gottwaldov (today called Zlín) and Ostrava.

The facts about the sorrowful ending of Rudolf Flachs' trade is testified by a letter of 10 August 1959, registered by the Popular Court (Lidový soud) in Třešt on 19 August 1959; here the named person is requested to 'incorporate the entertainment institutions into the permanent entertainment institutions of popular pastimes for the year 1960'. Eventually, the marionettist Rudolf Flachs ended up as a dustman for the town services of Mikulov (Fig. 11).

Turning the attention to Flachs's marionettes, these have survived as group holdings in various Czech marionette collections, held at the MZM in Brno, the Regional Museum in Mikulov, and in the private collections of Jiří Vorel in Prague, Milan Knížák in Prague and that of Marie and Pavel Jirásek in Brno. Other collectors own only single items. The largest collection of marionettes originating with the Moravian families of the Flachs is held in the Theatre History Department of the MZM in Brno. This is predominantly the original ensemble of Jana Flachs Jr. distributed among his children and further enlarged. The puppets were gradually acquired from several of the last owners (the Berouseks, the Flachs and the Kučeras). Among the rare items are the glove puppets and the rod puppets called mikrlata in the jargon; that is how marionettists termed the smaller puppets (of about $50 \mathrm{~cm}$ ) that had essentially the construction and appearance of a classical marionette but were controlled with a rod from below; the rod was a prolongation of one of the legs that was not articulated. In movement, the other leg and the arms only passively dangled. In contrast, the glove puppets had only a carved head and arms with forearms equipped with leather pockets to insert fingers (these pockets were coated in talcum powder before the play), and the body was created by the costume. Only Kašpárek had carved legs with calves attached to his costume. The heads of both the puppet types have an identical character and a texture of carving that matches other Flachs marionettes; only this time clearly more primitive. The typology of characters replicates those of Flachs' marionette ensembles. The mikrlata and the glove puppets were used by Czech marionettists only exceptionally but they played the same ('noble') repertoire as with the marionettes. Towards the end of their careers, the youngest of the Flachs were using them in school performances to play fairy tales. The MZM collection consists of eleven glove puppets of about $45 \mathrm{~cm}$ in height and twenty-eight mikrlata of about $50-55 \mathrm{~cm}$. There is no female character among the glove puppets; the mikralata have three of them.

The more commonly used marionettes are represented in two collections at the MZM. The heritage of Rudolf Flachs of Břeclava comprises sixteen marionettes of about $85-95 \mathrm{~cm}$ in height (Figs. 19, 23 and 24) with a control rod of about $120 \mathrm{~cm}$; out of them 4 are female characters; Kašpárek is $45 \mathrm{~cm}$ in height; the Dragon manipulated by strings 
is 97 by $15 \mathrm{~cm}$ in size and the Horse manipulated by strings is 30 by $25 \mathrm{~cm}$ in size. Apart from the so-called dupák (the stamping man), there are no variety puppets in the collection.

An absolute rarity is the collection of exceptionally tall marionettes acquired from the Berousek family (Figs. 13, 14, 15, 16 and 18). These thirteen marionettes of up to $105 \mathrm{~cm}$ in height are professionally carved, coloured and costumed. They have relatively short manipulating rods; the overall height does not exceed $135 \mathrm{~cm}$. The collection also comprises a fully carved Devil and a Death (Figs. 14 and 15) of the same size, both of which are manipulated only by strings, then a fully carved one-headed Dragon on strings. The collection contains only three female characters. The marionettes originally belonged to Jan Flachs Jr. although they had been probably acquired already by his father. According to the testimony by the Nový marionettist family of Bučovice, Jan Flachs Jr. kept this collection of 'giant' marionettes at home in memory of his father, while he performed with the smaller marionettes; those of about $80 \mathrm{~cm}$ in height are also testified by František Nevoral (see above; NEVORAL 1922: 110). The large marionettes were later inherited by Jan's eldest son Josef Flachs of Šumice near Uherský Brod. The last owner was eventually Josef's daughter Marie, married Berousková. Upon marriage to the famous family of travelling artists-ropedancers Karel and Rudolf Berousek, also known under their artistic name Blondi, Marie brought these marionettes as a dowry. The testimony of her husband Ignác (Hynek) Berousek suggests that the family did eventually put them to use. In a letter of 6 June 1967 (Sign. R), sent to the MZM's Theatre History Department, he writes:

Když s nimi můj otec hrál, měly svá jména, a to sedlák, selka, jich syn Kuba, dále kněžna Gorandina, kníže Rodelich, hrabě Leopold Švábský, jeho choț, dva loupežníci Belengárdo, jeden poustevník, baron Velenský, jeden stařec a rytír Břetislav.

[When my father played with them, they had their names, namely the Peasant, the Peasant Woman, their son Kuba, then Countess Gorandina, Count Rodelich, Earl Leopold of Swabia, his Wife, two highwaymen Belengárdo, one Hermit, the Baron Velenský, an Old Man and the Knight Břetislav.]

Marie Berousková also confirmed that the Berouseks had used to perform with these marionettes; she cited the above-mentioned play of Jenovéfa, in which she called the relevant marionettes in the collection by the characters' names. One of the smaller figures a young man - does persuasively refer with its size and appearance to the character of Jenovéfa’s son Bolestín (the Suffering One).

Two of the significant volumes of alleged Flachs' marionettes are held in two private collections in Prague - Jiří Vorel's (Figs. 21c and 21d) and Milan Knižák’s (Figs. 20a, 20b, $21 \mathrm{a}$ and $21 \mathrm{~b}$ ), the greater part of which can currently be seen in the long-term exhibition 'Milan Knížák’s Puppet Museum' on the second floor of the Lednice Château and also in 


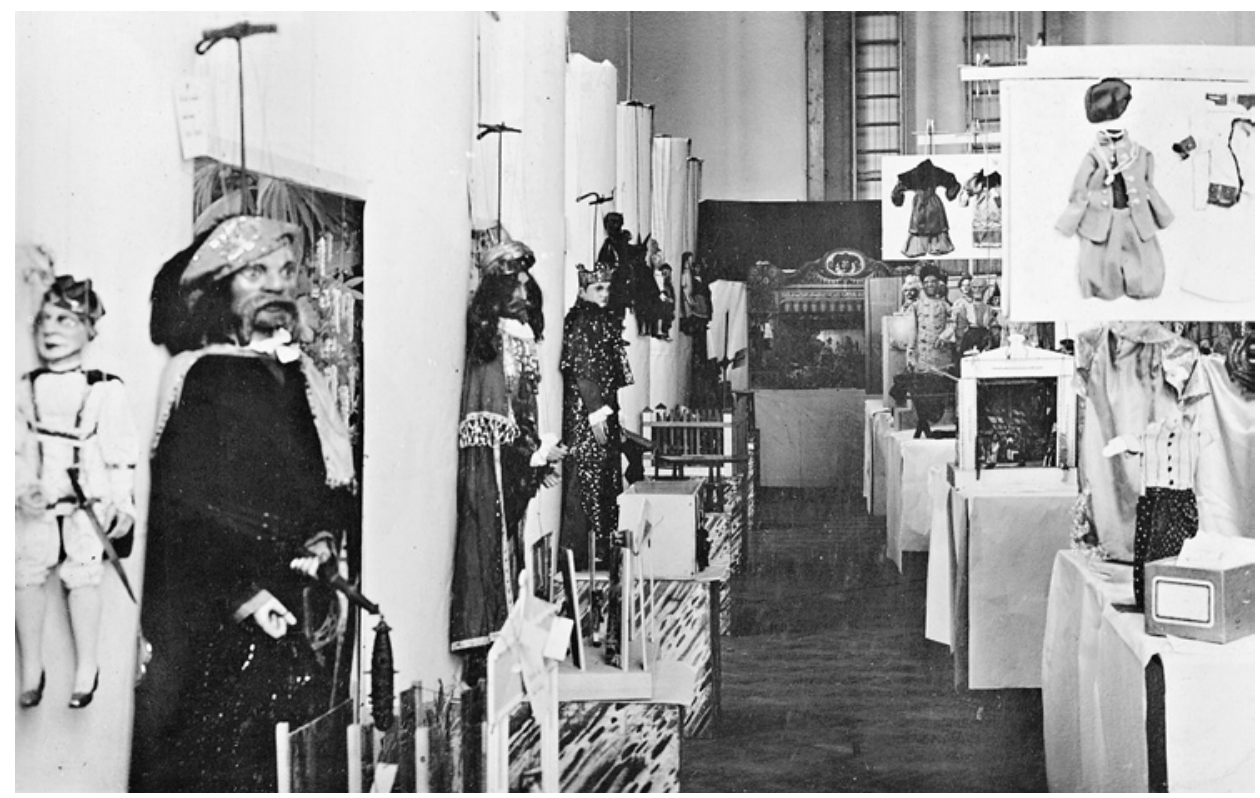

Fig. 17: Marionettes belonging to Josef Flachs at a puppetry exhibition in Uherský Brod, 1936. (C) Collections of MZM.

the 'Puppet Museum' in Štramberk. In both cases, the marionettes' origin is unconfirmed. According to the information available, they were acquired gradually, namely from the descendants of the Flachs family relatives, from antique shops and from art dealers.

Milan Knížák's collection contains about twenty such marionettes of $80-90 \mathrm{~cm}$ in height, in several generationally graded types. Jiř́ Vorel's collection contains two incomplete sets - altogether also around twenty examples of large marionettes of $80-90 \mathrm{~cm}$ on average. In both Knížák's and Vorel's collections, male figures dominate; there are only three female ones in the former and only two in the latter. Neither holds any variety puppets, with the exception of a dupák in the Vorel collection.

The private collections of the Jiráseks, a part (fifteen pieces) of the Flachs' set of smaller puppets (glove puppets and mikrlata) has survived. It also contains a minimum of female figures (merely three). As late as the early 1970s, Rudolf Flachs of Brno (born 1928, the son of Jan Flachs, born 1891) performed with these puppets as a worker of the state-owned Brno Culture and Leisure Park (Park kultury a oddechu v Brnè). This is testified by the surviving 'Permit' č. Kult. 1971-LTZ/Sm of 27 January 1971 that:

povoluje s. Rudolfu Flaksovi [...] vstup do obcí okresu Brno-venkov, a to v souladu s ujednáním o provozu loutkoherectví s Parkem kultury a oddechu odboru rekreace a lidové zábavy v Brně. 
[gives permission to c. [comrade] Rudolf Flaks [...] to enter the environs of Greater Brno, and perform in keeping with the arrangement on the practising of puppetry with the Brno Culture and Leisure Park, Department of Recreation and Popular Pastimes.]

All of the above puppets are characteristic of their peculiar and identical appearance. Simply and succinctly, they can be characterised as Václav Nedbal did: as having 'exceptionally nice, broad and distinctive carving' (NEDBAL 1912: 99). At first sight, they are marked by their high protruding foreheads, exaggerated superciliary arches (the ridges on the frontal bone of the skull, above the eye socket), wide-set eyes and a thick nasal bridge. In some particulars they may resemble the 'Sucharda' carving of the renowned Nová Paka workshop (originally established by Jan Sucharda Jr., the workshop trained a generation of woodcarvers who made traditional marionettes as well as sacred objects). The style is similar with their half-open mouths and protruding teeth on the folk characters. They show attributes of a similar carving, both in proportions (the texture of the faces, hair, beards, the placement of eyes, slimmed arms and legs etc.), and in details (the schematic wrinkles and dimples on the foreheads, in cheeks, in mouth corners, in palms, on the backs of hands or on finger joints). Very often identical types (indicating characters) appear, differing only in minute nuances. The general rule is that there are few female figures and those are not very successful in terms of their physiognomy.

The findings to date suggest that these visually specific marionettes were held only by the families of Flachs and those related to them. For these 'proprietary' reasons, they are often mechanically considered for the works of the Flachs themselves, namely of Jan Flachs Sr. and Jan Flachs Jr. However, their actual origin has not been confirmed despite a number of agreeing claims of contemporaries, and so it remains disputed. None of the surviving photographs of marionettes and marionette ensembles of the well-known or less-known puppeteers, as have mostly been published in the journal Loutkár, show the Flachs' puppets. This is surprisingly also true of the many documents of puppetry exhibitions organised by Jindřich Veselý, which were considered by 'conservative' marionettists and supporters of puppet theatre as highly prestigious. The fact that these high-quality puppets were not owned by any other dynasty appears a true mystery. If the artefacts were the products of a private workshop, other marionettists would certainly have known about it and it would have become much sought after. There are no related puppets (or even sculptures) in evidence in the provenience of the neighbouring countries either.

Unfortunately, there are no extant photographs of the early practice of the Flachs, with the exception of three. The first captures Jan Flachs Jr. sitting in front of his caravan with his marionettes (Fig. 7); the photograph is undated but comes from the late 1920s. ${ }^{3}$ The image shows thirteen marionettes, out of which eight male figures: Kašpárek (who cannot be fully seen), two female figures, one devil and one death. These marionettes

3 The original $(6 \times 5 \mathrm{~cm})$ from the heritage of Jan Malík is deposited in the collections of the Chrudim Puppetry Museum (Muzeum loutkárských kultur v Chrudimi); a reproduction was published in Loutkár XIV/7-8 (1928): 155. The photograph is by Ing. František Čech. 


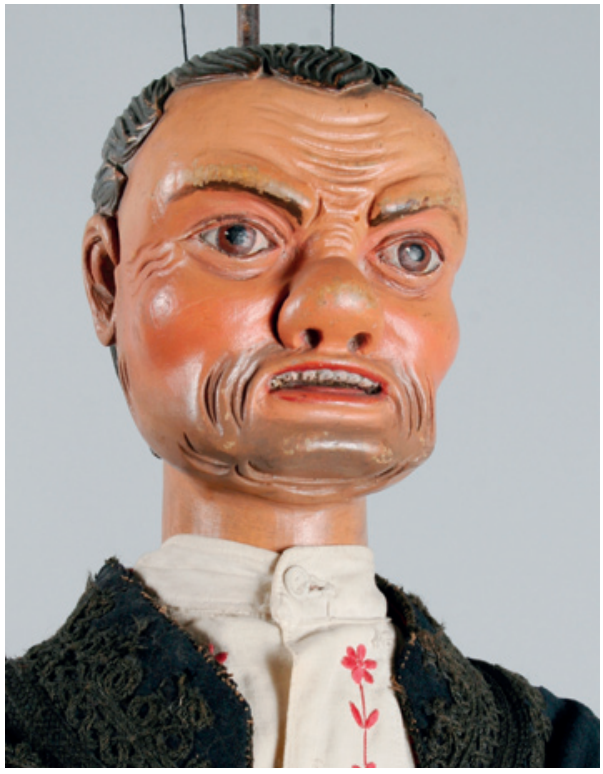

Fig. 18: The Peasant, a reiterating folk type. The largest marionette from the Flachs family exclusive set of the 'Berouseks'.

(c) Collections of MZM. Photo (C) Jaroslav Blecha.

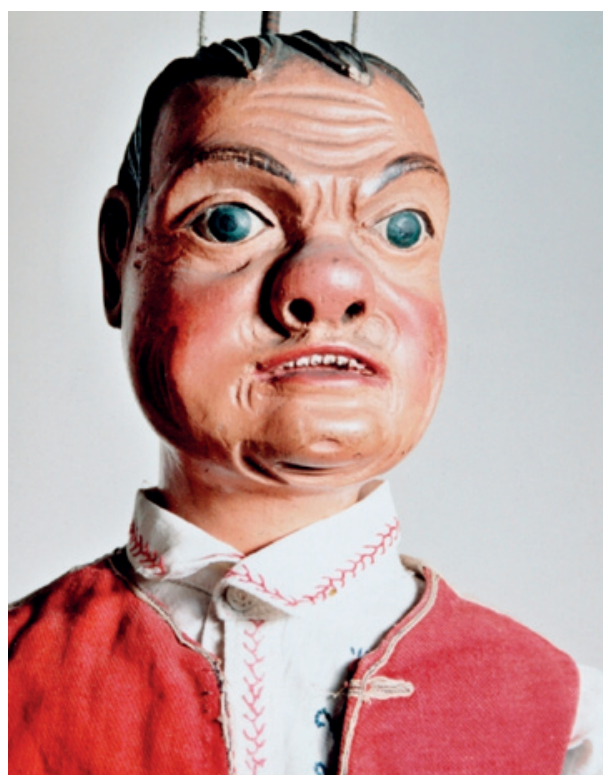

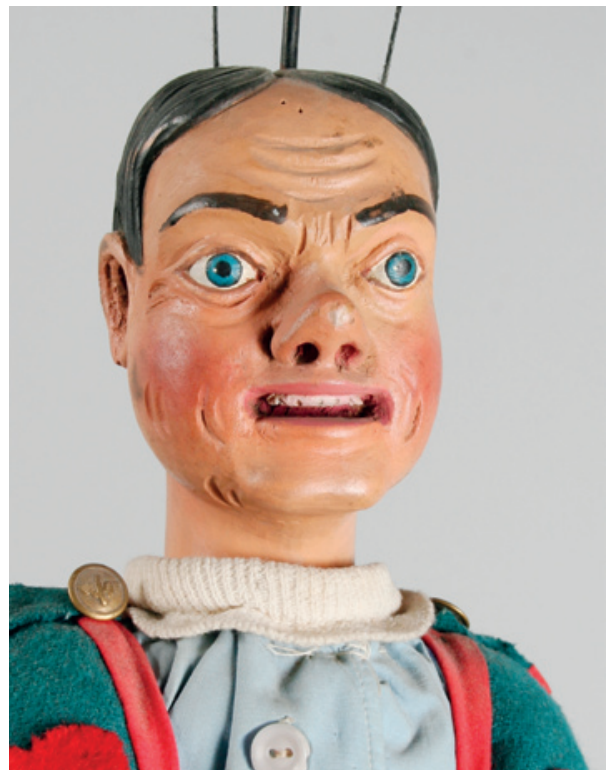

Fig. 19: The Peasant, a reiterating folk type.

A smaller marionette of the Flachs; the Rudolf Flachs set.

(C) Collections of MZM. Photo (C) Jaroslav Blecha.

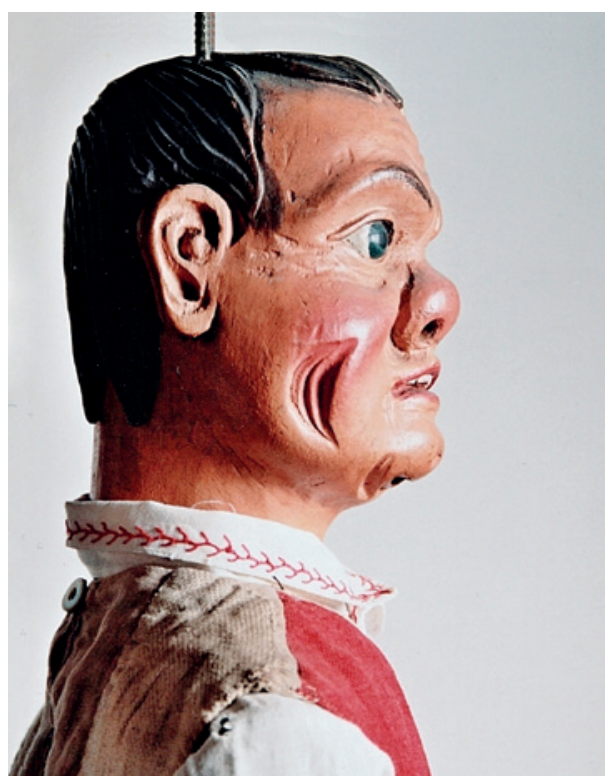

Fig. 20a+b: The Peasant, a reiterating folk type. A smaller marionette of the Flachs of unknown provenance. (c) Collections of MK. Photo (c) M. Brhel. 
The Enigmatic Puppets of Important Czech Marionettists, the Flachs
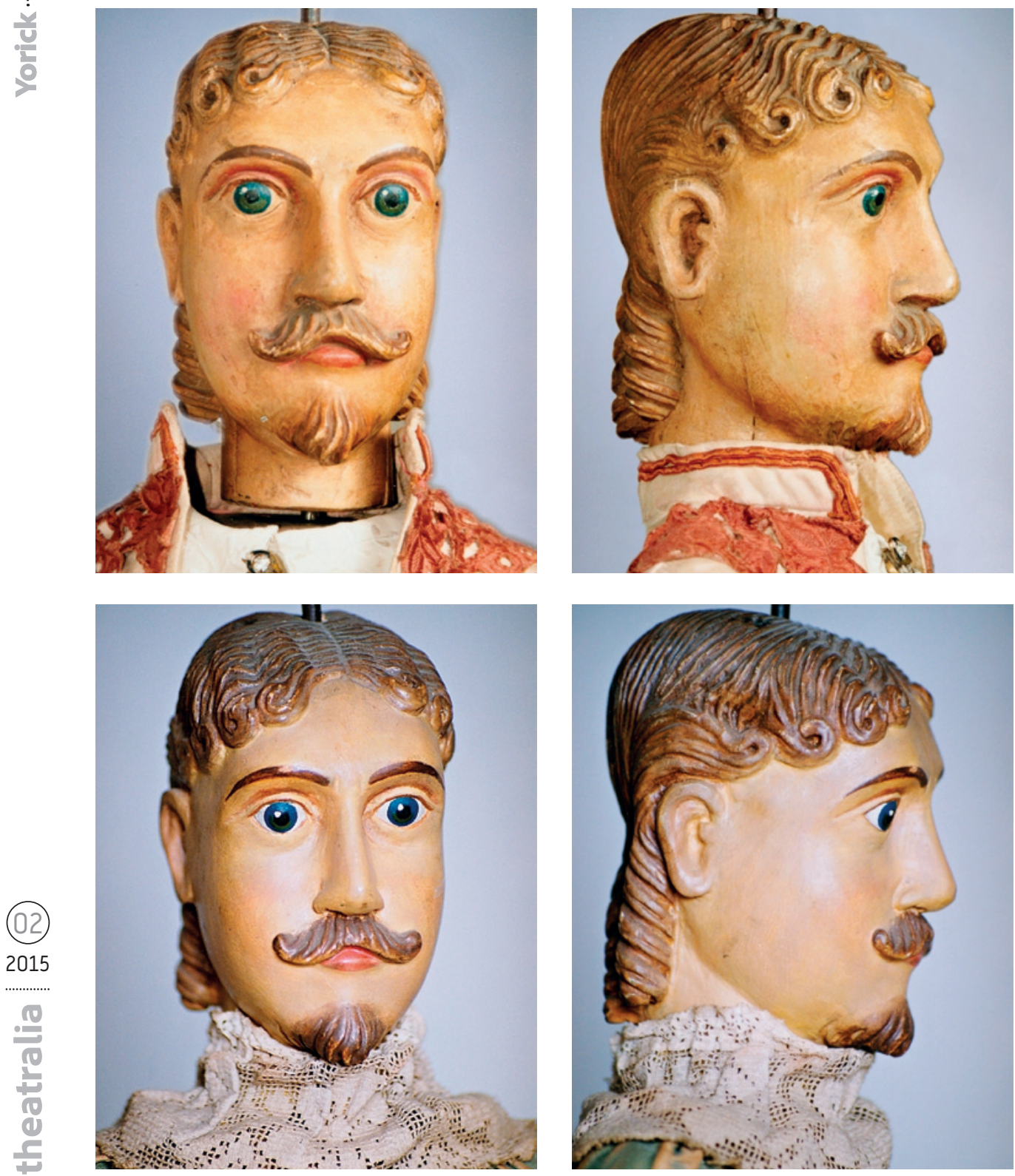

Fig. 21a-d: An Aristocrat with a beard, a reiterating folk type. A smaller marionette of the Flachs of unknown provenance. ๑ Collections of MK. Photo $\odot$ M. Brhel. 
are generally around $80 \mathrm{~cm}$ in height except for the smaller Kašpar, as is conventional. In contrast, the fully carved devil is exceptional in being proportionately larger, at around $100 \mathrm{~cm}$. This is clearly the figure surviving in the exclusive Berousek collection at the MZM. This shows that Jan Flachs Jr. did make use of the collection of 'giant' marionettes, although sporadically or selectively. The disproportionately large devil perhaps did not disturb next to the other characters; maybe it was even convenient. Also, some of the other marionettes can be identified within the later holdings of the MZM, namely in the collection from Jan's son Rudolf. Undoubtedly this is the case of the fully carved and unpainted death, the two aristocrats and the peasant. The technically weak and faded photograph nevertheless shows that all the marionettes (perhaps with one exception) correspond in character to the Flachs type of carving. It is strange that none of the pictured marionettes contain girdled features in their costume, such as breastplates or helmets. Probably the maker was unable to produce them and was limited in means to acquire them elsewhere. However, all the extant collections discussed above have these costume accessories for the aristocratic and chivalric figures. These are the fine artistic work of a quality girdler - decorative enchased brass breastplates and helmets - especially in the Berousek collection, some are specimens of demanding artwork. However, there are not many of them and the marionette maker probably had them made bespoke. Knížák's collection has at least three such instances; Vorel's has two. In the MZM holdings, the Berousek collection has three such fully equipped figures and there are two among Rudolf Flachs's marionettes. The mikrlata have no such accoutrements except for a primitively made royal crown.

Two photographs of a much later time come from the regional puppetry exhibition in Uherský Brod in 1936; they show three marionettes belonging to Josef Flachs (the 'Berouseks') and 'Flachs' smaller puppet theatre', with a round dance and a juggler with an umbrella in the background (Fig. 17). Besides the aforementioned dupák (stamping men), these are the only recorded variety puppets of the Flachs marionette ensembles. It may therefore seem that the Flachs family did not perform the traditional pridánka (encore) in such an extensive form as other marionettists.

The extant Flachs marionettes can be divided into three separate categories: (1) puppets of accurate woodcarving, gilding and girdling work (as is the case of the Berousek puppets and most of the smaller marionettes in the other collections); (2) puppets of relatively well crafted schematic carving with crude colouring (which in some instances may be cases of later repainting); and (3) dilettante creations, although often rather successful, imitating professional models (this is true of most of the glove puppets and mikrlata; certainly these are the work of the alleged creators (i.e. the marionettists themselves, Rudolf Flachs, Josef Flachs and others).

Where did all the finer marionettes of the 'higher category' that show signs of professional making actually come from? Most of them, including the Berousek marionettes, were owned by Jan Flachs Jr. He had probably inherited some of the marionettes from 
his father. The collection of large marionettes was probably among them. However, their ultimate origin is unknown. In this context, the information provided by Václav Truhlár are of interest. Jan Flachs Sr., who was his father-in-law, passed on to him his trade licence in 1851. As the documents of April 1851 suggest, Truhlár had his own puppets and those were of exceptional quality:

zabývá se loutkovým divadlem od mládí a vynaložil celé jmění svoje i své manželky, přes 800 zl., na opatření divadla a krásných figur. (BARTOŠ 1963: 178)

[He has occupied himself with puppet theatre since his youth and has expended his own and his wife's entire fortune, over 800 guldens, to acquire a theatre with beautiful figures.]

It is unknown which carver or workshop provided Truhlár with the marionettes. The fate of his trade, namely of these marionettes, in Truhlár's family after 1857, is unknown. Hypothetically it cannot be ruled out that they passed to the Flachs and became a showcase of younger carving for the eventuality that these would be made by the family members themselves.

Jan Flachs Jr. himself expressed his pride to František Nevoral saying that he carved his marionettes himself, 'showing [him] nice half-finished work in his wagon' when they met on his tour (NEVORAL 1922: 110). Jan's followers occasionally mention this too. What was then passed by word of mouth among the Flachs?

Emilie Kočková, née Flachsová (daughter of Rudolf Flachs), recalled that 'granddad' Jan Flachs Jr. had trained as a joiner:

Whenever he found a piece of lime wood, he would make a head, then the legs, the body [...] his wife (Emilie) had no training, mother (Cecílie) taught her to be a seamstress, buying the material for costumes from rag-pickers.

The sons of Jan Flachs Jr., Josef and Rudolf, recalled in unison that the marionettes had been carved by the two Jans - father and grandfather. This information was regurgitated by other followers of Flachs and by the related marionettist families of Kučera and Nový. Rudolf Flachs also said of the set of large marionettes that they had been made by his father Jan Flachs Jr., and he confirmed that he never played with them: 'Nožíky měl děda $\mathrm{z}$ brìtev a furt dělal a furt dělal.' ('The old man had his knives made of razors and he kept making and kept making.') With the experience of similar claims of other marionettists, such as Václav and Karel Kopecký (Brno), it can be assumed that these are probably hearsay or conventional sayings of marionettists, through which they enhanced their own popularity. So, for instance, of the puppets undoubtedly made by the carvers Mikoláš Sychrovský, Jan Mádle or Jaroslav Vaněk, both the Kopeckýs claimed that they had been made by one of their ancestors. Objective judgment is further complicated by 


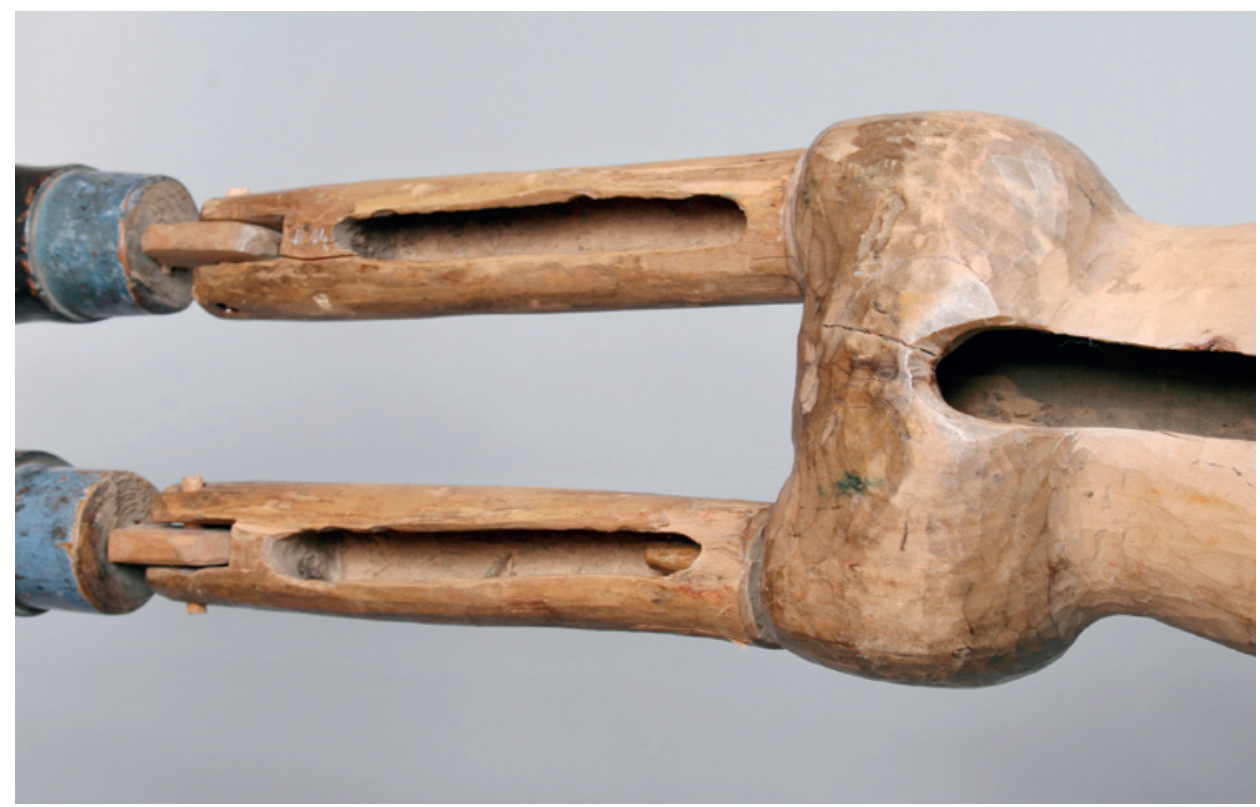

Fig. 22: The largest marionette from the Flachs family exclusive set of the 'Berouseks'; note the typical 'hollowing' of the trunk and the legs of the Flachs puppets. (C) Collections of MZM. Photo (C) Jaroslav Blecha.

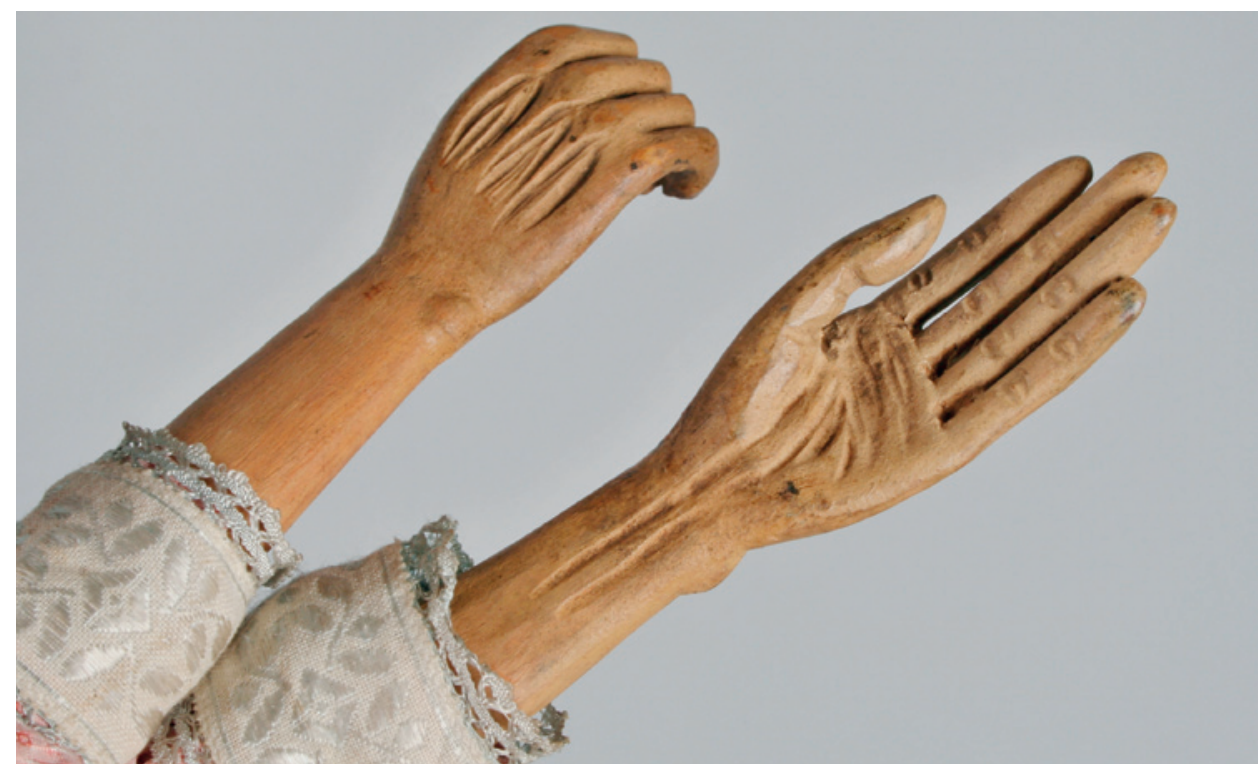

Fig. 23: A smaller marionette of the Flachs; the Rudolf Flachs set; note the typical execution of the carving of hands of the Flachs puppets. (c) Collections of MZM. Photo (c) Jaroslav Blecha. 
Jaroslav Blecha

The Enigmatic Puppets of Important Czech Marionettists, the Flachs

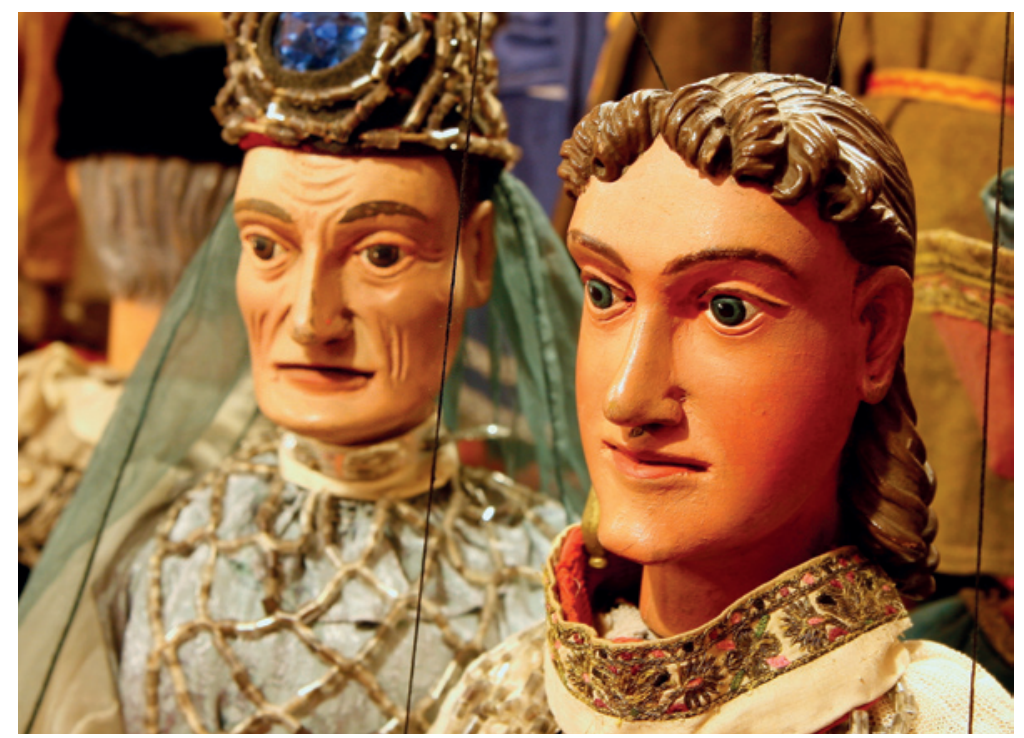

Fig. 24: Marionettes of the Queen and the Countess from the Rudolf Flachs set. (c) Collections of MZM. Photo (C) Jaroslav Blecha.

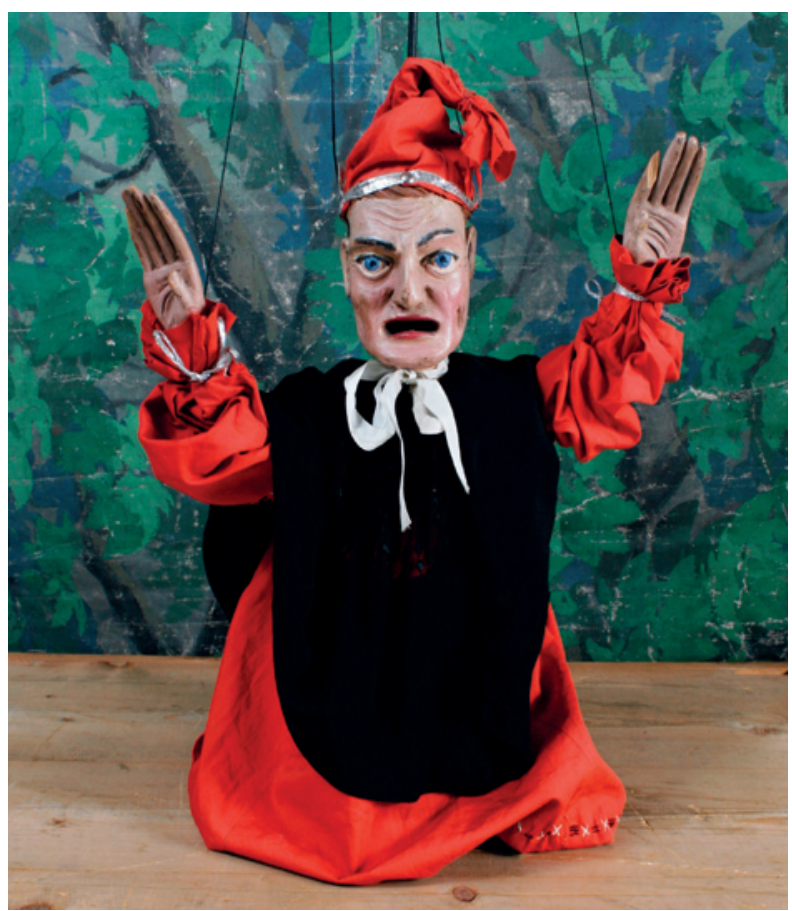

Fig. 25: Puppet of the Dupák (the stamping man) from the Rudolf Flachs set. (c) Collections of MZM. Photo (C) Jaroslav Blecha. 
the problem of dating the anonymous puppets. The seemingly idiosyncratic attributes can be generalised only with the utmost wariness. These are matters such as the size of the marionettes, the proportions of the head, the body and the arms and legs, the carving technique, the colouring techniques, the measure of neutrality or the expressiveness of the aspects etc.

It is assumed that the earliest Czech marionettes were of a smaller height, around $60 \mathrm{~cm}$ and their proportions approximated the human body. Larger marionettes, up to $120 \mathrm{~cm}$, probably started to appear only much later. A number of sources testify to a larger variety. Marionettes of some $120 \mathrm{~cm}$ were in the possession of Tomáš Kopecký (1825-1894). Older, similarly tall puppets are recorded with foreign puppeteers operating in the Czech lands, such as Johann Baptist Hilverding (1677-1721; the use recorded in the late 1600s) or Anton Joseph Geissler (?-1723; use recorded in 1713). Of similar disputability are the techniques of carving and polychromy. The creation of marionettes was the work of trained carvers, expedient in Baroque figural sculpting, as well as tradesmen carvers and folk carvers who mastered their artistic trade to the same standards (and often excellently) but did not deploy the strict normatives of Baroque sacred sculpture. Some created puppets in a similar vein, including a complex technology of polychromy. In this process, a chalk base (known as šeps, calcium carbonate) under the final colour, was laid onto a perfectly smooth surface that was glued (mucilaged, to balance absorption) or puttied. Others made their lives easier by colouring the wood without the chalking, only solidified with mucilage (glue water, a process known as trenkovánî). In the case of amateur creations by self-taught makers, though visually talented, the results were naturally anomalies originating in ignorance of the trade. All this suggests that even a large puppet may come from an early production and that a puppet with traditional polychrome painting can be younger than one that is coloured directly on the wood and so on. In other words, neither the size of the puppets, the nature of carving, the colouring techniques or the construction can be the determining factors in relation to their age and provenance.

In his deductions over the Flachs marionettes, Milan Knížák ruled out the Flachs as their creators on the basis of the above usage and other prerequisites. As decisive factors, he considers 'the number and size of extant puppets', the necessary 'provision of wood' that would be unthinkable with a travelling marionettist; 'the changes in marionettist handwriting suggestive of the long-term and gradual development of the creator', 'the fluctuation in the accuracy of the execution', 'a perfect work with the detail in carving' and 'the insufficient knowledge of human anatomy' (KNÍŽÁK 2006: 261-2). Knížák's observations seem rather logical, although they can be contradicted in many ways. Effectively, for all the indices of the origin of the Flachs' marionettes there are contradictory arguments. As for the number of extant marionettes, it is no excessive count. There are thirteen of the enormous ones and about sixty of the smaller. At the same time, the smaller show signs of at least dual quality and indicate generational differences rather than a 'gradual development of the author'. Which of them were made 
earlier and which later cannot be unambiguously confirmed. That means they could have been created in two or more generations, which would also explain the 'fluctuations in the accuracy of the execution' rather than un-proficient lapses. The question of availability of quality wood is also irrelevant given the longer time span in the creation of the puppets. The lime tree is copiously present in the Czech lands, so lime wood used to be commonly available. Minute carving, such as that of the marionette heads, can be done much more easily in fresh un-dried wood (so-called wet carving) than in dried wood, without the wood going through substantial deformations or cracks in drying. That means high-quality dry wood is not essential for such usage. Equally, the acceptance of anatomical proportion was not very significant in the case of the marionettes in question. It seems the maker subjected the work to a good or even practical knowledge of marionette-making practice. Except for certain simplifications (or caricatures) in the facial detail, this is suggested in the execution of the bodies and the arms and legs with a careful hollowing and articulation (Fig. 22). The smaller marionettes are executed in a much simpler fashion than the larger figures. A profound analysis of the surviving puppets suggests that in reality their carving is not very complex and its perfect texture is not limited by the professional tools used, such as special carving chisels.

Principally no overly complex and complicated features are present that would be unachievable with common joiner's gouge chisels supplemented by a few (perhaps even self-made) basic shaping gouges. The carving is certainly executed with a noblesse that gives it effect and dynamism. Seemingly the most complex are the hair curls of several aristocratic types. These 'grow' on the back of the head from a simple corrugated fluting (vrapování, žlábkování) of the hair. With its cylindrical openwork carving they are reminiscent of drapes in ornamental woodcarving or the decorative motifs of ropes created by barley twist carving (tordováni). However, in most instances they are rather schematic (Figs. $21 \mathrm{~b}$ and 21d). Their basics can be in fact made even with a straight chisel with the so-called 'cut splines' technique applied in opposing angles, or with a straight gouge (semi-circular in blade shape) with moon-shaped indentations. Most of the other puppets have hair and beards more or less straight or only mildly wavy, indented with a narrow and deep straight gouge (of semi-circular shape). It seems that except for the indentation of the eyes and the mouths the ' $\mathrm{V}$-shape' (also known as 'goat foot') was not much used; but even for these, the ' $\mathrm{V}$ ' tool (or straight parting tool) is not essential. Even an amateur can acquire sufficient improvised tools, such as shallow straight gouges, hammered from rolled iron pipes or narrow deep semi-circular gouges made from the iron wires of an umbrella and so on. ${ }^{4}$ As far as the colouring of the Flachs' marionettes is concerned, there is no extant instance of classical polychromy with a talcum base.

4 In my leisure time, I practise amateur puppetry carving. For empirical reasons I have previously copied one of the Berousek marionette heads. I intentionally used a block of lime wood meant for burning; it was a piece of a stronger bough and the wood was therefore deep and not very thick (from a professional point of view, this was low quality material). I had only common joiner's chisels and gouges and common linocut gouges. Making a practically perfect copy including colouring took me three days of some ten hours each. 
This suggests that these high-quality puppets could have been made by a talented dilettante, especially if trained in a related trade (such as joinery or cabinetmaking). The doubt that these were made by a professional woodcarving workshop is raised by two facts. Firstly, there are no other extant marionettes that would be similar or sculpturally analogous to the Flachs' artefacts. Secondly, these puppets clearly do not come from a single time period - as would be the case if they had been made bespoke in a single exclusive commission. Furthermore, these are not puppets of the earliest generations of the Flachs dynasty, but rather marionettes made in the second half or even the very end of the nineteenth century. The hypothesis that the puppets could have been made (and maintained) by a member or members of the Flachs family is further supported by other circumstantial evidence. Almost all pluri-generational ensembles of puppets are heterogeneous. Besides a certain basic set of figures that is gradually and amateurishly modified (through repainting, replacements of heads, re-carving of the hair etc.), there are often additions of other provenience, such as completely new puppets or variously combined components. In the case of the Flachs of Jan Flachs Sr.s generation, that is not the case - their marionette collection comes as uniform, and if the puppets were undergoing modifications or renovations, these were executed by a 'single hand' that retained their style.

There are many factors suggesting that the 'luxury' set of large marionettes, the 'Berouseks' - disregarding who used their great invention and handcraft to make them was a model set for the smaller marionettes that were used in performance. These replicate with minor variations and in several iterations all the types and basic features of the large marionettes, both in their composition and in their details. The texture of the carving of most of them is, however, less cultivated, coarser, although still technically and visually well crafted. It cannot be ruled out that the Flachs made marionettes for themselves and for their related families. Unfortunately, the evidence that would either reliably confirm or negate this hypothesis has not yet come to light.

The Moravian branch of the Flachs dynasty undoubtedly belongs to the important history of marionettist families practising travelling puppet theatre with a good portion of talent, systematically, intensively and to the full capacity of its significance. The continuity of the trade between Jan Flachs the Eldest down to his great grandchildren, especially Rudolf, brings testimony of the typical Czech marionettists of the time, who maintained the tradition of the marionette theatre in its stable and highly stylised form without any striking evolutionary changes. Had it not been for the forceful administrative rupture that took place in the post-WW2 period, the descendants would probably most likely have practised the art until today. The Flachs surely belong to the ranks of puppeteers who saw their theatre not only as a way of making a living, but also as a noble mission. For that reason, as well as the fact that a potential talented creator of their marionettes among the larger family has not yet been found, they deserve on-going critical attention. 


\section{Bibliography}

BARTOŠ, Jaroslav. 1952. Loutkářské hry českého obrození [Puppet Plays of the Czech National Revival]. Praha: Československý spisovatel, 1952.

BARTOŠ, Jaroslav. 1959. Komedie a hry českých lidových loutkářu [Comedies and Plays of the Czech Folk Puppeteers]. Praha: Orbis, 1959.

BARTOŠ, Jaroslav. 1960. Loutkáři 17. a 18. věku v Čechách, na Moravě a ve Slezsku [Seventeenthand Eighteenth-Century Puppeteers in Bohemia, Moravia and Silesia]. Praha: Státní pedagogické nakladatelství, 1960.

BARTOŠ, Jaroslav. 1963. Loutkářská kronika [The Puppeteers' Chronicle]. Praha: Orbis, 1963.

BLECHA, Jaroslav. 1996. O českém pimprlovém divadle [On the Czech Glove-Puppet Theatre]. Brno: Muzeum města Brna, 1996.

BLECHA, Jaroslav. 1998. Loutkářská sbírka Moravského zemského muzea v Brně [The Puppetry Collection of the Moravian Museum in Brno]. Semily: Muzeum and Pojizerská galerie v Semilech, 1998.

BLECHA, Jaroslav. 2004. Př́spěvek k poznání geneze a specifik původních českých marionet [A Contribution to the Understanding of the Genesis and Specifics of Original Czech Marionettes]. Acta Mus. Moraviae, Sci. soc. LXXXIX (2004): 245-52.

BLECHA, Jaroslav, Pavel JIRÁSEK and Václav JIRÁSEK. 2008. Česká loutka [The Czech Puppet]. Praha: Kant, 2008.

DUBSKÁ, Alice. 1992. Obtížné hledání souvislostí (Př́íspěvek k výzkumu českého loutkového divadla národního obrození) [The Difficult Search of Connections (A Contribution to the Research in Czech Puppet Theatre of the National Revival]. Divadelni revue [Czech Theatre Review] 2 (1992): 36-44.

DUBSKÁ, Alice. 2004. Dvě století českého loutkářství [Two Centuries of Czech Puppetry]. Praha: Akademie múzických umění, 2004.

DUBSKÁ, Alice. 2010. Putující loutkářské rody a jejich opony [The Travelling Puppeteer Families and their Curtains]. In Malované opony divadel českých zemí [Decorated Theatre Curtains of the Czech Lands]. Praha: Národní informační a poradenské středisko pro kulturu v Praze - NIPOS, 2010: 353.

DUBSKÁ, Alice. 2011. Cesty loutkárư Brátů a Pratte Evropou 18. a 19. století [Travels of the Puppeteers Brát and Pratte thorough $18^{\text {th }}$ and $19^{\text {th }}$ Century Europe]. Praha: Akademie múzických umění, 2011.

KAŠ, Josef. 1947. O řezbárích a tiskářích lidových českých loutkářů [On the Carvers and Printers of the Czech Folk Puppeteers]. Českýlid [The Czech People] (1947): 153.

KNİŽÁK, Milan. 2006. Encyklopedie výtvarníků loutkového divadla v českých zemích a na Slovensku od vystopovatelné minulosti do roku 1950 [An Encyclopaedia of the Visual Artists of the Puppet Theatre in the Czech Lands and in Slovakia from the Traceable Past to 1950]. Hradec Králové: Nucleus, 2006.

KOČKA, Bohumil. 2010. Vzpomínky Bohumila Kočky na Rudolfa Flachse [Bohumil Kočka’s memoires of Rudolf Flachs]. In Třri Radosti moravského loutkáře Vladimíra Matouška. Loutkové di- 
vadlo v Břeclavi [Three Delights of Moravian Puppeteer Vladimír Matoušek. Puppet Theatre in Břeclav]. Břeclav: Klub přátel umění Břeclav a Vlastivědná společnost regionu Břeclavsko, 2010: 76-7.

KOPECKÝ, Antonín. 1919. Působení tři legionářů-loutkářu [The Activities of Three LegionaryPuppeteers]. Loutkár̆ IV/1 (1919): 8-9, IV/2 (1919): 19-21.

KOPECKÝ, Antonín. 1933. Ve šlépějích praděda loutkáře. Vzpomínky z války a legií [In the Footsteps of Great-Grandfather Marionettist. Memories of War and the Legions.]. Brno: Moravský legionář, 1933.

KOTRBA, Heřman. 1982. Trísky z dílny řezbáře [Shavings from the Woodcarver’s Workshop]. Brno: Nakladatelství Blok, 1982.

KOTRČOVÁ, Milena. 1984. Lidový loutkář Rudolf Flachs [The Folk Marionettist Rudolf Flachs]. In Milena Kotrčová, Jaroslav Zika and Mirko Matoušek. Historie a současnost loutkářství v Břeclavi [The Past and Present of Puppeteering in Břeclav]. Břeclav: Dům kultury ROH, 1984: 29-30.

MALÍK, Jan. 1964-70. Z letopisů dřevěné thálie [From the Chronicles of the Wood Thalia]. Československý loutkář [The Czechoslovak Puppeteer] XIV-XX (1964-70).

MALÍK, Jan, Jan DVOŘÁK, Josef ŠECHTL and Marie ŠECHTLOVÁ. 1978. Svět loutek [The World of Puppets]. Hradec Králové: Kruh, 1978.

MINÁR̆, Marek. 2005. Řezbářství [Woodcarving]. Praha: Grada Oublishing, a. s., 2005.

MINÁŘ, Marek. 2008. Lidové řezbářství [Folk Woodcarving]. Praha: Grada Publishing, a. s., 2008.

NEDBAL, Václav. 1912. Z Rožmitála [From Rožmitál]. Českýloutkář [The Czech Puppeteer] I/3 (1912): 99.

NEVORAL, František. 1922. Lidový loutkář Jan Flachs [The Folk Marionettist Jan Flachs]. Loutkář [The Puppeteer] VI/7 (1922): 96, VI/8 (1922): 110.

PATKOVÁ, Jindřiška. 1970. Loutkářské sbírky Národního muzea [The Puppetry Collections of the National Museum]. Acta scaenographica 2-XI (1970): zadní předsádka [endpaper].

PAVLÍČEK, František and Jana VAŇKOVÁ. 1987. O dřevěné komedii na Moravě [On the Wooden Comedy in Moravia]. Brno: Moravské muzeum, 1987.

PORT, Jan. 1953. Loutkářské památky v Národním museu v Praze [Puppetry Collections in the National Museum in Prague]. Československý loutkár [The Czechoslovak Puppeteer] III/4 (1953): 92.

STOKLAS, Eugen. 1928. Antonín Scheich. Loutkář [The Puppeteer] XIV/7-8 (1928): 152.

ŠRÁMKOVÁ, Vítězslava and Jiří VALENTA. 2002. Místopis českého amatérského divadla [A Local History of the Czech Amateur Theatre]. Praha: Informační a poradenské středisko pro místní kulturu, útvar ARTAMA, 2002.

TELCOVÁ, Jiřina. 1971. Z loutkáŕovy maringotky [From the Marionettist’s Caravan]. Brno: Moravské museum, 1971.

TELCOVÁ, Jiřina. 1975. Loutky z maringotek [Marionettes from the Caravans]. Loutkářské listy 3 (1975): 36.

TELCOVÁ, Jiřina. 1979. Moravské lidové loutky [Moravian Folk Puppets]. Brno: Moravské muzeum, 1979. 
Jaroslav Blecha

The Enigmatic Puppets of Important Czech Marionettists, the Flachs

VEIL, Emanuel. 1923. Z činnosti loutkoherce Josefa Flachse [On the Activities of the Puppeteer Josef Flachs]. Loutkár̆ [The Puppeteer] X/4 (1923): 60.

VESELÝ, Jindřich. 1916. Scénář vybraných her loutkových kdekoli vydaných [A Scenario of Selected Puppet Plays Published Anywhere]. Praha: A. Storch syn, 1916.

VESELÝ, Jindřich. 1925. Jména lidových českých loutkář [The Names of Czech Folk Puppeteers]. Loutkáŕ [The Puppeteer] XII/1 (1925): 19-20.

ZÁTKA, František. 1918. Jihočeští loutkáři lidoví z 2. polovice XIX. století [South Bohemian Folk Puppeteers of the Late $19^{\text {th }}$ Century]. Loutkár [The Puppeteer] II/od č. 7 (1918): 89.

\section{Sources}

Puppets from the collections of the Moravian Museum, the Theatre History Department, Brno: collections 'Berousek' (sign. L1-L15), collection R. Flachs (sign. L40-L61, L81), collection V. Flachsová (sign. L1046-1065), collection A. Kučera (sign. L1198-L1216).

Puppets from the collections of Milan Knížák, Praha, without classmarks.

Puppets from the collections of Jiří Vorel, Praha, without classmarks.

Puppets from the collections of Marie and Pavel Jirásek, Brno, without classmarks.

The memoires and correspondence of the Moravian Museum with Marie Berousková, Hynek Berousek, Rudolf Flachs, Vlasta Nová and Václav Kučera. Collections of the Moravian Museum, the Theatre History Department, Brno: sign. A, R, incl. sound recordings (magnetic tapes and digitalised files) sign. E.

Written documentation from the heritage of the families of Flachs, Nový and Kučera. Moravian Museum, the Theatre History Department, Brno: sign. A. 


\section{Summary}

This article brings summative information in relation to the Flachs, one of the leading families of traditional Czech folk marionettists. It focuses on the last three generations, from the mid-nineteenth century to the decline of itinerant family marionette troupes in the 1950s. The article also analyses extant puppets made and used by the family and their distinctive carving techniques.

\section{Keywords}

Czech puppet theatre, puppet makers, puppet carvers, marionettes, traditional theatre, folk theatre, travelling theatre, Flachs

Translated by Pavel Drábek

DOI: $10.5817 /$ TY2015-2-2

Jaroslav Blecha (blecha@mzm.cz) graduated in Theatre, Music and Museum Studies at the Faculty of Arts, Masaryk University. He is Head and Curator of the Department of Theatre History, Moravian Museum, specialising in Czech marionette theatre, in particular itinerant performers and family theatres. He has presented his findings at exhibitions, in print, on radio and in television programmes, and at public lectures and talks. His most important exhibitions were Česká loutka (The Czech Puppet), held at Prague Castle, under the auspices of President Václav Havel (2002-2003), and the largest Czech marionette presentation to date, A Window to Czech Marionette Art in Tolosa, Spain, at the Titirijai 07 Festival. With Pavel Jirásek he published a monograph entitled Česká loutka (The Czech Puppet, 2008). He has published two monographs on Czech toy theatres, Rodinná loutková divadélka: skromné stánky múz (Family Marionette Stages: The Humble Temples of the Muses, Brno: MZM, 2009) and Rodinná loutková divadélka: herectvo na drátkách (Family Marionette Stages: The Thespians on Wires, Brno: MZM, 2013). 